\title{
Stable isotope variability in a Chilean fjord food web: implications for $\mathbf{N}$ - and $\mathbf{C}$-cycles
}

\author{
Christoph C. Mayr ${ }^{1,2,7, *}$, Günter Försterra ${ }^{3}$, Verena Häussermann ${ }^{1,3}$, \\ Anja Wunderlich ${ }^{4}$, Jürke Grau ${ }^{1,5}$, Moritz Zieringer ${ }^{6}$, Alexander V. Altenbach ${ }^{1,2}$ \\ ${ }^{1}$ GeoBio-Center, and ${ }^{2}$ Department für Geo- und Umweltwissenschaften, Ludwig-Maximilians Universität, \\ Richard-Wagner Str. 10, 80333 Munich, Germany \\ ${ }^{3}$ Huinay Scientific Field Station, and Pontificia Universidad Católica de Valparaíso, Escuela de Ciencias del Mar, \\ Facultad de Recursos Naturales, Avda. Brazil 2950, Valparaíso, Chile \\ ${ }^{4}$ Institut für Grundwasserökologie, Helmholtz Zentrum München, Ingolstädter Landstrasse 1, 85764 Neuherberg, Germany \\ ${ }^{5}$ Department Biologie I, Bereich Biodiversitätsforschung-Botanik, Ludwig-Maximilians Universität, Menzinger Str. 67, \\ 80638 Munich, Germany \\ ${ }^{6}$ IFM-GEOMAR, Leibniz Institute of Marine Science, 24148 Kiel, Germany \\ ${ }^{7}$ Present address: Institut für Geographie, Friedrich-Alexander-Universität Erlangen-Nürnberg, Kochstr. 4/4, \\ 91054 Erlangen, Germany
}

\begin{abstract}
We analysed carbon $\left(\delta^{13} \mathrm{C}\right)$ and nitrogen $\left(\delta^{15} \mathrm{~N}\right)$ isotope ratios of organisms and biogenic tissues from Comau Fjord (southern Chile) to characterise benthic food webs and spatial isotope variability in this ecosystem. These values were intended to serve as a baseline for detecting anthropogenic impacts on Patagonian marine fjord ecosystems in later studies. Benthic macroalgae and invertebrate suspension feeders were primarily considered, with some supplementary data from cyanobacteria, plankton, fish, and coastal vertebrates. Six depth transects typified the lateral salinity gradients from the innermost part of the fjord to its mouth, as well as the vertical density gradients caused by freshwater inflow. Carbon isotope signatures indicated predominant consumption of either $\mathrm{CO}_{2}$ or $\mathrm{HCO}_{3}{ }^{-}$for benthic macroalgal. All $\mathrm{CO}_{2}$ users belonged to rhodophytes. The $\delta^{15} \mathrm{~N}$ values of benthic macrophytes decreased with decreasing salinity, both vertically and along the fjord axis. This implies the influence of ${ }^{15} \mathrm{~N}$-poor terrestrial dissolved inorganic nitrogen (DIN) at these sites. Enhanced influence of freshwater influx also lowered $\mathrm{N}$ contents and increased $\mathrm{C} / \mathrm{N}$ ratios in algal tissues. Exceptionally high macroalgae $\delta^{15} \mathrm{~N}$ values at the seabird and sealion colony Isla Liliguapi point to animal faeces as an additional source of ${ }^{15} \mathrm{~N}$-enriched DIN. Thus, DIN sources not originating from the open sea are additionally utilised by the benthic macroalgae in the fjord. In contrast, mussel tissue from the same locations was much less influenced by varying DIN sources. Among benthic suspension feeders, mytilids (Mytilus chilensis, Aulacomya ater) had the lowest and scleractinian corals (Desmophyllum dianthus) had the highest $\delta^{15} \mathrm{~N}$ values, and Balanidae (Elminius kingii) and gorgonians (Primnoella sp.) showed values in between. The preference for specific size classes of marine particulate organic matter (seston) as food serves as an explanation for the $\delta^{15} \mathrm{~N}$ variability observed between the different benthic suspension feeders.
\end{abstract}

KEY WORDS: Patagonian fjord - Nutrient sources · Marine food web · Nitrogen · Carbon · Benthic macroalgae $\cdot$ Suspension feeders $\cdot$ Trophic isotope enrichment

Resale or republication not permitted without written consent of the publisher

\section{INTRODUCTION}

The Chilean fjord region south of $42^{\circ} \mathrm{S}$ is facing rapid economic development, but detailed investigations of its benthic communities just started a little more than a decade ago (Arntz \& Rios 1999, Fernandez et al. 2000, Escribano et al. 2003). Biodiversity studies revealed a variety of novel species, as well as taxa with unusual distributions and habitats (e.g. Försterra \& Häussermann 2003, 2008, Häussermann \& Försterra 
2007, van Ofwegen et al. 2006, Esteves et al. 2007, Försterra et al. 2008, Sinniger \& Häussermann 2009). The driving forces behind these patterns are not yet fully understood (Fernandez et al. 2000, Escribano et al. 2003). Possible environmental factors affecting biodiversity are specific physical and chemical gradients or highly dynamic nutrient and organic matter fluxes. However, few oceanographic data are available (e.g. Pickard 1971, Silva et al. 1995, 1998, Strub et al. 1998). An understanding of the functioning of the Chilean fjord ecosystem is a prerequisite in order to assess the consequences of the intensified exploitation of marine resources and of rapidly expanding aquaculture, the latter adding additional nutrient sources to benthic ecosystems. In addition to species inventories, a deeper understanding of the biogeochemical cycles in Patagonian fjords is the basis for environmental monitoring.

Stable isotope methods are frequently applied to characterise marine food webs (Minagawa \& Wada 1984, Schoeninger \& DeNiro 1984, Bergmann et al. 2009, Steinarsdóttir et al. 2009). The nitrogen and carbon isotopic compositions of natural samples are given as delta values $(\delta)$, representing the isotope ratio of the heavy to the light isotope (\%o) relative to an international standard and is defined as: $\delta^{y} X=\left(R_{\text {sample }} /\right.$ $R_{\text {standard }}-1$ ) $\times 1000$, with $R$ being the ratio of the heavier to the lighter isotope $\left({ }^{15} \mathrm{~N} /{ }^{14} \mathrm{~N}\right.$ and ${ }^{13} \mathrm{C} /{ }^{12} \mathrm{C}$, respectively) and ${ }^{y} X$ being the heavier isotope (i.e. ${ }^{15} \mathrm{~N},{ }^{13} \mathrm{C}$ ).

The carbon isotope composition $\left(\delta^{13} \mathrm{C}\right)$ of an organism can be used to distinguish isotopically different sources in food webs (DeNiro \& Epstein 1978). Minor $\delta^{13} \mathrm{C}$ differences of 0 to $1 \%$ are observed between animals and their food (Peterson \& Fry 1987). Thus, the much larger carbon isotope discrepancies between certain groups of primary producers can be traced throughout marine food webs (Fry \& Parker 1979, McLeod \& Wing 2009).

In contrast to carbon, the nitrogen isotope composition of animal tissue is generally more enriched in the heavy isotope relative to its food, due to preferential excretion of ${ }^{14} \mathrm{~N}$ (DeNiro \& Epstein 1981, Minagawa \& Wada 1984, Peterson \& Fry 1987, Vanderklift \& Ponsard 2003). The resulting ${ }^{15} \mathrm{~N}$ enrichment in animal tissue is $3.4 \%$, on average, for each trophic level (Wada et al. 1987, Post 2002). Hence, nitrogen isotope data of organisms have been used to determine the number of trophic levels in ecosystems (e.g. Hobson \& Welch 1992, Bergmann et al. 2009) and to evaluate the trophic level of individual taxa relative to others (Struck et al. 2002). Moreover, spatial and seasonal isotopic variability in benthic organisms can occur, particularly in estuarine and coastal habitats, due to changing availability of isotopically different $\mathrm{N}$ and $\mathrm{C}$ sources (Deegan \& Garritt 1997, Riera et al. 1999, Baeta et al. 2009). Body mass can also have an influence on the $\delta^{15} \mathrm{~N}$ signatures of benthic organisms (Jennings et al. 2008), whereas anthropogenic effluents into coastal habitats provide additional ${ }^{15} \mathrm{~N}$-enriched nitrogen sources that can be traced in marine organisms (McClelland et al. 1997, Riera et al. 2000, Costanzo et al. 2001, Rogers 2003).

Here, results of an isotopic survey of organisms and organic matter from Comau Fjord, Chile, are presented. Comau Fjord is located in the northern part of the Patagonian fjord region, approximately $100 \mathrm{~km}$ SSE of the city of Puerto Montt (see Fig. 1). The fjord has a maximum length of $41 \mathrm{~km}$, a mean width of $4.5 \mathrm{~km}$ and mean mid-inlet depth of $420 \mathrm{~m}$ (Pickard 1971). Due to the steep walls of the fjord and the absence of paved roads, the catchment of Comau Fjord is sparsely populated and mainly covered by primary temperate rain forest. Comau Fjord represents a relatively pristine marine ecosystem in Chile, as it is not yet heavily affected by aquaculture or exploitation of seafood.

The aim of the present study was to provide the first comprehensive isotope dataset of Chilean fjord organisms, to determine their nutrient and food sources as well as trophic levels. Furthermore, we wanted to test whether spatial and depth salinity gradients, and potentially coexistent nutrient and food changes, influence the isotopic signatures of the organisms. To test this hypothesis, we focussed on fixo-sessile primary producers (benthic macroalgae) and benthic suspension feeders collected at various sites and depths in the fjord.

\section{MATERIALS AND METHODS}

Sampling sites. Benthic marine organisms were sampled in January 2007 and in March 2008 by SCUBA divers at 6 locations and at different depths along the axis of Comau Fjord. A few samples were already taken in October 2006. Locations were chosen along a salinity gradient from the most open-marine site, the island Isla Liliguapi at the mouth of the fjord, to the most freshwater-influenced site, Punta Huinay in front of the mouth of the Rio Loncochaigua (Fig. 1). Samples were taken from 4 different water depths (high, mid- and low intertidal and subtidal). Due to the large tidal amplitude in this region $(>7 \mathrm{~m})$ and the temporal and spatial variability of the thickness of the low salinity layer (LSL), indicator organisms and tidal charts were used to determine sample depth. The high intertidal is herein defined as the zone only briefly covered with superficial fjord water with low salinity. The mid-intertidal zone is under water and exposed in equal time intervals. When covered by water, it is usually still in the LSL, but occasionally salinities may be higher. The low intertidal is only sporadically exposed 


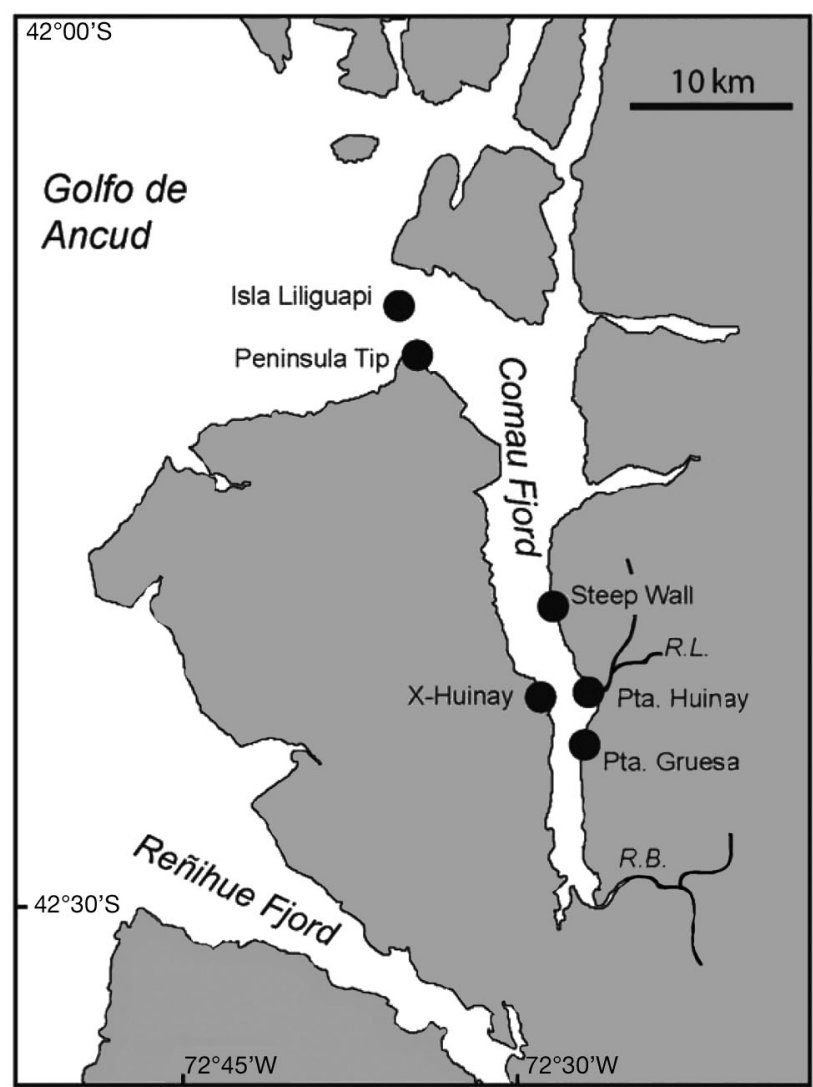

Fig. 1. Comau Fjord with the 6 sampling locations. Major rivers close to the sampling sites are also given. R.B.: Río Bodudahue; R.L.: Río Loncochaigua

to air and under the influence of water with varying salinities. Due to the wind-protected situation of Comau Fjord, spray water is of minor importance for intertidal organisms. Subtidal samples were taken from depths below the influence of the LSL. Among the sessile benthic organisms, macroalgae (various taxa of chlorophytes, rhodophytes and phaeophytes) and the mytilid bivalve Mytilus chilensis were present at every depth and location. The mytilid Aulacomya ater was only absent in the upper intertidal. Therefore, these organisms were sampled preferentially to evaluate the depth and spatial isotopic variability of organisms. Seston samples were obtained close to Punta Huinay with a plankton net of $45 \mu \mathrm{m}$ mesh size from the uppermost $\sim 20 \mathrm{~m}$ of the water column in October 2006 and at various locations during a phytoplankton bloom in March 2010. In the field laboratory, seston samples were further separated into different fractions by careful wet sieving with filtered seawater through a tower of stainless steel-wire sieves (Retsch) with mesh widths of 45, 63, 125, 250 and $500 \mu \mathrm{m}$. Finally, the seston samples were rinsed once with deionised fresh water. The 2010 composition of seston size fractions was examined microscopically. Fish were caught with artificial baits on fishing lines from a reel with a depth counter.

Depth profiles and nitrate analyses. In March 2008, depth profiles of basic physical and chemical parameters ( $\mathrm{pH}$, salinity, temperature) were determined with a portable field meter (Universal Pocket Meter MultiLine P4, WTW Ltd) at each location immediately after recovery of samples. Sampling was carried out with a water sampler (Limnos) attached to a steel cable and a manual winch with a digital meter counter (Uwitec) mounted on board the RV 'Huinay'. Water samples for nitrate analyses were sampled with a Niskin bottle, transferred into $20 \mathrm{ml} \mathrm{PE}$ bottles and frozen after sampling. Prior to analysis, selected samples were thawed and filtered through cation exchange resin cartridges (OnGuard II Ag, Dionex) to remove chloride from the sample matrix. Nitrate concentrations of the chloridefree water samples were analysed with an ion chromatography system (DX 100, Dionex) using nitrate standard solutions with concentrations from 0.8 to $16.1 \mu \mathrm{mol} \mathrm{l}^{-1}$. Nitrate concentrations $<0.3 \mu \mathrm{mol} \mathrm{l^{-1 }}$ were below the analytical limit and not evaluated.

Sample treatment and taxonomy. At the Huinay scientific station, samples were dried in an oven at $40^{\circ} \mathrm{C}$ within a few hours after sampling. After thorough drying, samples were immediately sealed in evacuated plastic bags and kept frozen until shortly before the isotope analyses were carried out. Prior to analysis, all samples were homogenised with a mortar. If possible, whole organisms were homogenised. Muscle tissues were analysed from fishes, because homogenisation of the whole body was not practical. For $\delta^{13} \mathrm{C}$ analyses, calcareous parts of animals were completely removed prior to homogenisation (mussels), or, if this was not possible (e.g. for calcareous sponges), carbonate was removed by acidification with $5 \% \mathrm{HCl}$. All $\delta^{15} \mathrm{~N}$ analyses are from non-acidified samples. Benthic invertebrates and fishes were identified based on Häussermann \& Försterra (2009). Macroalgal taxonomy was based on Santelices (1989), Ramírez \& Santelices (1991) and Guiry \& Guiry (2009).

Stable isotope analyses. Samples were weighed in tin capsules and combusted at $1080^{\circ} \mathrm{C}$ in a continuous helium flow in an elemental analyser (NC2500, Carlo Erba) in the presence of chromium oxide and silvered cobalt oxide. Among the resulting gases, nitrogen oxide and excess oxygen were reduced by passing over copper wires at $650^{\circ} \mathrm{C}$. Thereafter, water vapour was trapped with $\mathrm{Mg}\left(\mathrm{ClO}_{4}\right)_{2}$, and the remaining gases $\left(\mathrm{N}_{2}\right.$ and $\left.\mathrm{CO}_{2}\right)$ were separated in a gas chromatography column at $45^{\circ} \mathrm{C} . \mathrm{N}_{2}$ and $\mathrm{CO}_{2}$ were passed successively via a ConFloII interface into the isotope ratio-mass spectrometer (Delta Plus, Thermo-Finnigan) and isotopically analysed. Carbon and nitrogen contents were 
determined from the peak area versus sample weight ratio of each individual sample and calibrated with the elemental standards cyclohexanone-2,4-dinitrophenylhydrazone $\left(\mathrm{C}_{12} \mathrm{H}_{14} \mathrm{~N}_{4} \mathrm{O}_{4}\right)$ and atropine $\left(\mathrm{C}_{17} \mathrm{H}_{23} \mathrm{NO}_{3}\right)$ (Thermo Quest). A laboratory-internal organic standard (Peptone) was used for final isotopic calibrations. Isotope values are reported as per mil values relative to international standards (air for nitrogen and Vienna PeeDee Belemnite for carbon). Analytical precision was typically $0.1 \%$ for both $\delta^{13} \mathrm{C}$ and $\delta^{15} \mathrm{~N}$ (1 standard deviation). All element concentrations given are weight percentages relative to dry weight and have an analytical error of $<5 \%$ of the given value. Statistical tests were carried out with the software PASW Statistics 17.0 (SPSS).

\section{RESULTS}

\section{Physical and chemical depth profiles}

The depth profiles recorded at the 6 sites in late austral summer (20 to 28 March 2008) exhibited salinities between 12.3 and 24.5 at the surface $(0.1 \mathrm{~m}$ water depth) and haloclines between 5 and $10 \mathrm{~m}$ water depth (Fig. 2). Repeated measurements at 2 locations showed that surface salinities could vary greatly within a few days (11.7 and 24.5 at Steep Wall, 5.3 and 17.0 at
$\mathrm{X}$-Huinay). Below $10 \mathrm{~m}$ depth, the freshwater influence ceased; salinity increased only a little from 33.1 (15 m) to 33.9 (200 m; Fig. 2).

Temperature and $\mathrm{pH}$ profiles showed slightly different patterns than salinity (Fig. 2). The surface temperature was around $15.5^{\circ} \mathrm{C}$, except at those locations close to river inflows. At these locations, surface temperatures were lower by 1 to $2^{\circ} \mathrm{C}$. The temperature decreased to ca. $11.8^{\circ} \mathrm{C}$ in the underlying thermocline, which reached a depth of ca. $30 \mathrm{~m}$ at all sites. At $\mathrm{X}$-Huinay, a temperature of $10.9^{\circ} \mathrm{C}$ was recorded at $200 \mathrm{~m}$ depth. Average $\mathrm{pH}$ values followed the trends of the thermoclines, but decreased only a little from 8.2 to 7.8 and remained at that level at greater depths. Nitrate concentrations were low $\left(<1.0 \mu \mathrm{mol} \mathrm{l}^{-1}\right)$ in water samples from the surface to a depth of $30 \mathrm{~m}$, at those locations for which nitrate analyses were made (X-Huinay, Punta Huinay, Peninsula Tip). At lower depths, nitrate concentrations increased and reached a maximum value of $3.0 \mu \mathrm{mol} \mathrm{l}^{-1}$ at a depth of $200 \mathrm{~m}$ at X-Huinay (Fig. 2).

\section{Isotopic signatures of different organisms}

The $\delta^{13} \mathrm{C}$ and $\delta^{15} \mathrm{~N}$ values of various taxonomic groups and of potential nutrient and food sources are summarised in Table 1 . The $\delta^{15} \mathrm{~N}$ values of
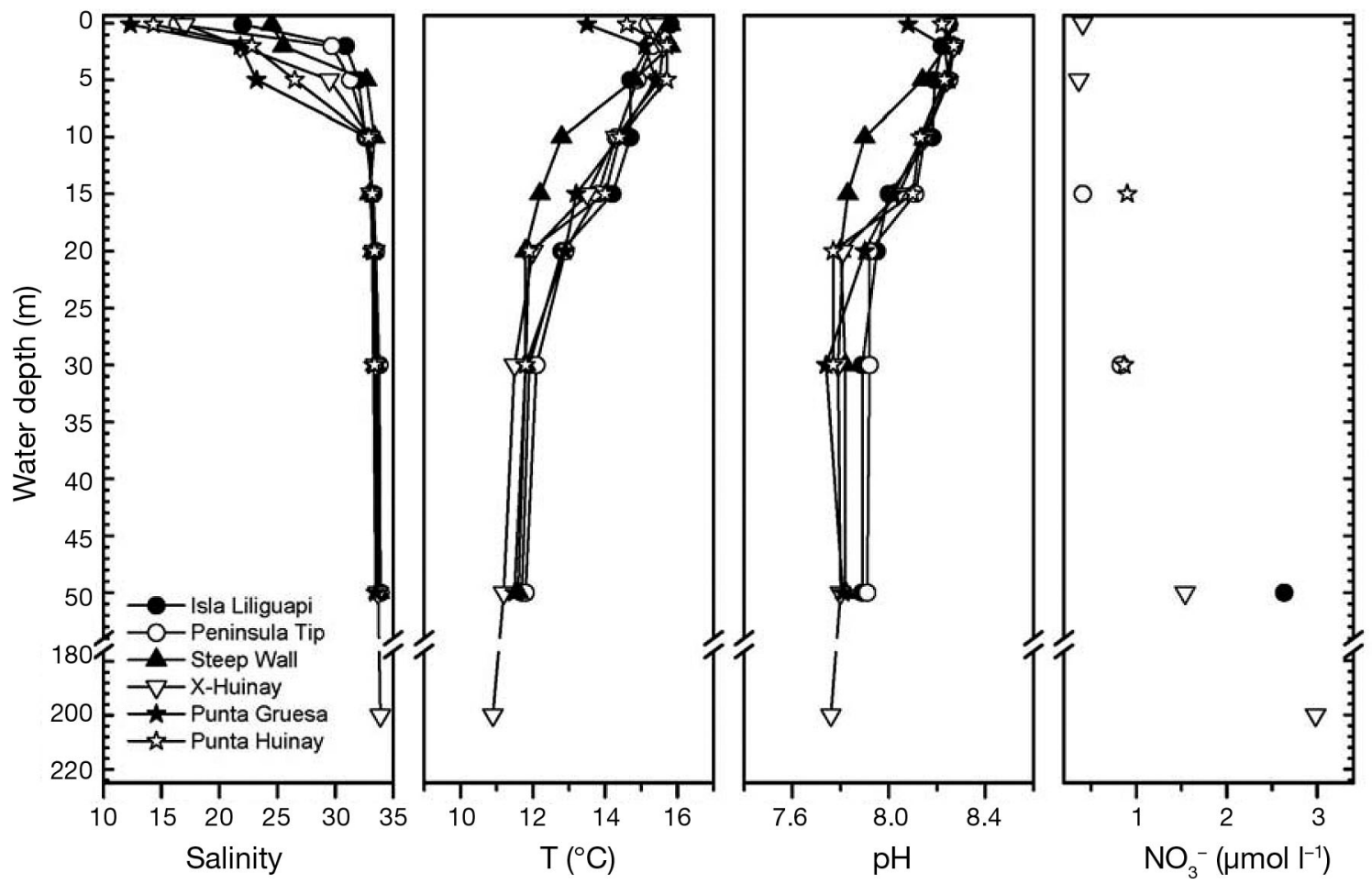

Fig. 2. Depth profiles of salinity, temperature (T), $\mathrm{pH}$ and nitrate $\left(\mathrm{NO}_{3}{ }^{-}\right)$concentration recorded at the 6 sampling locations in March 2008 
Table 1. $\delta^{15} \mathrm{~N}, \delta^{13} \mathrm{C}$ and molar $\mathrm{C} / \mathrm{N}$ values of organisms and organic matter from Comau Fjord and its catchment. Given are mean values, standard deviations (SD) of the mean (or absolute differences for $\mathrm{n}=2$ ) and number of samples $(\mathrm{n})$. Locations, depths and trophisms are abbreviated-PG: Punta Gruesa; IL: Isla Liliguapi; SW: Steep Wall; PT: Peninsula Tip; XH: X-Huinay; PH: Punta Huinay; IT: intertidal; ST: subtidal; PP: primary producers; GR: grazers; SF: suspension feeders; CV: carnivores; PV: planktivores

\begin{tabular}{|c|c|c|c|c|c|c|c|c|c|c|c|c|}
\hline Taxon & $\delta^{15} \mathrm{~N}$ & $\mathrm{SD}$ & $\mathrm{n}$ & $\delta^{13} \mathrm{C}$ & $\mathrm{SD}$ & $\mathrm{n}$ & $\mathrm{C} / \mathrm{N}$ & $\mathrm{SD}$ & $\mathrm{n}$ & Location & Depth & $\begin{array}{l}\text { Troph- } \\
\text { ism }\end{array}$ \\
\hline \multicolumn{13}{|l|}{ Cyanobacteria } \\
\hline Rivularia atra, Gloeocapsa & -0.3 & & 1 & -9.3 & & 1 & 9 & & 1 & PG & IT & $\mathrm{PP}$ \\
\hline \multicolumn{13}{|l|}{ Chlorophytes } \\
\hline Chaetomorpha linum & 10.9 & & 1 & -12.8 & & 1 & 9 & & 1 & IL & IT & PP \\
\hline Chordaria magellanica & 7.5 & & 1 & -14.3 & & 1 & 16 & & 1 & PG & ST & PP \\
\hline Cladophora perpusilla & 10.6 & 1.6 & 2 & -12.9 & 0.2 & 2 & 9 & 1 & 2 & IL & IT & PP \\
\hline Enteromorpha spp. & 8.0 & 2.2 & 48 & -16.1 & 2.0 & 48 & 32 & 23 & 48 & $\begin{array}{l}\text { PG, SW, IL, } \\
\text { PH, PT, XH }\end{array}$ & ST, IT & PP \\
\hline Rhizoclonium sp. & 4.9 & & 1 & -11.9 & & 1 & 9 & & 1 & PG & IT & $\mathrm{PP}$ \\
\hline Ulothrix sp., diatoms & 6.4 & 0.5 & 3 & -18.8 & 3.5 & 3 & 21 & 3 & 3 & $\mathrm{XH}, \mathrm{PH}$ & IT, ST & PP \\
\hline Ulva spp. & 10.0 & 2.1 & 40 & -14.8 & 1.7 & 39 & 18 & 14 & 40 & $\begin{array}{l}\text { PT, IL, PH, } \\
\text { XH, PG, SW }\end{array}$ & IT, ST & $\mathrm{PP}$ \\
\hline \multicolumn{13}{|l|}{ Phaeophytes } \\
\hline Halopteris funicularis & 7.3 & & 1 & -19.5 & & 1 & 15 & & 1 & PG & IT & PP \\
\hline Macrocystis sp. & 8.4 & 0.9 & 14 & -15.7 & 1.5 & 14 & 20 & 5 & 14 & $\mathrm{PG}, \mathrm{PH}, \mathrm{SW}, \mathrm{XH}$ & ST, IT & PP \\
\hline Myrioglae chilensis & 7.4 & & 1 & -14.7 & & 1 & 15 & & 1 & PG & ST & PP \\
\hline Pylaiella sp. & 6.5 & & 1 & -17.0 & & 1 & 12 & & 1 & PG & IT & PP \\
\hline Scytothamnus fasciculatus & 9.6 & 0.3 & 3 & -14.1 & 0.8 & 3 & 25 & 4 & 3 & PT & IT & PP \\
\hline Phaeophytes indet. & 11.2 & & 1 & -18.0 & & 1 & 6 & & 1 & PH & IT & $\mathrm{PP}$ \\
\hline \multicolumn{13}{|l|}{ Rhodophytes } \\
\hline Bostrychia radicans & 6.9 & 1.6 & 6 & -29.2 & 4.1 & 6 & 18 & 5 & 6 & $\mathrm{PG}, \mathrm{PH}, \mathrm{XH}$ & IT & PP \\
\hline $\begin{array}{l}\text { Ceramium stichidiosum, } \\
\text { Polysiphonia sp. }\end{array}$ & 8.9 & & 1 & -18.3 & & 1 & 9 & & 1 & $\mathrm{XH}$ & ST & PP \\
\hline Gigartina skottsbergii & 9.3 & 0.1 & 3 & -26.0 & 5.2 & 3 & 16 & 4 & 3 & PT, IL & $\mathrm{ST}, \mathrm{IT}$ & PP \\
\hline Gracillaria (?) lemanaeformis & 7.7 & 0.3 & 2 & -18.7 & 0.1 & 2 & 22 & 3 & 2 & $\mathrm{PH}$ & ST & PP \\
\hline Griffithsia chilensis & 8.8 & & 1 & -23.4 & & 1 & 7 & & 1 & PT & $\mathrm{ST}$ & PP \\
\hline Hypnea sp. & 7.8 & & 1 & -18.5 & & 1 & 11 & & 1 & SW & IT & PP \\
\hline Iridaea ciliata & 8.8 & & 1 & -16.5 & & 1 & 17 & & 1 & $\mathrm{PT}$ & ST & PP \\
\hline Myriogramme multinervis & 8.2 & 0.5 & 4 & -31.0 & 1.9 & 4 & 9 & 2 & 4 & PG, SW & ST & PP \\
\hline Myriogramme crozieri & 7.7 & 0.9 & 4 & -31.0 & 0.5 & 4 & 10 & 1 & 4 & PG, PH, SW & $\mathrm{ST}$ & PP \\
\hline Porphyra columbina & 12.6 & 2.8 & 3 & -17.4 & 4.1 & 3 & 17 & 4 & 3 & IL, PT & IT & PP \\
\hline Rhodymenia howeana & 8.8 & 0.4 & 4 & -29.6 & 2.7 & 4 & 10 & 2 & 4 & $\mathrm{IL}, \mathrm{PT}, \mathrm{SW}, \mathrm{XH}$ & $\mathrm{ST}$ & PP \\
\hline Schizoseris dichotoma & 8.8 & 1.4 & 2 & -31.3 & 4.5 & 2 & 7 & 0.4 & 2 & PT, SW & $\mathrm{ST}$ & PP \\
\hline Rhodophytes indet. & 8.1 & 1.1 & 3 & -20.3 & 1.1 & 3 & 21 & 11 & 3 & PG, PH, SW, PT & ST, IT & $\mathrm{PP}$ \\
\hline \multicolumn{13}{|l|}{ Porifera } \\
\hline Callyspongia sp. & 10.7 & 1.0 & 2 & -19.0 & 1.1 & 2 & 4 & 0 & 2 & $\mathrm{PT}$ & $\mathrm{ST}$ & $\mathrm{SF}$ \\
\hline Axinella crinita & 12.7 & & 1 & -19.9 & & 1 & 6 & & 1 & SW & & \\
\hline Dramacidon egregia & 15.9 & & 1 & -18.0 & & 1 & 5 & & 1 & SW & & \\
\hline \multicolumn{13}{|l|}{ Cnidaria } \\
\hline Desmophyllum dianthus & 14.5 & 0.8 & 21 & -16.3 & 1.8 & 24 & 5 & 0.5 & 5 & & ST & $\mathrm{SF}$ \\
\hline Primnoella sp. & 13.3 & 0.6 & 6 & -18.5 & 0.5 & 6 & 5 & 0.4 & 3 & $\begin{array}{c}\text { XH, PG, SW, } \\
\text { PT, IL }\end{array}$ & $\mathrm{ST}$ & SF \\
\hline \multicolumn{13}{|l|}{ Molluscs } \\
\hline Aulacomya ater & 10.6 & 0.9 & 8 & -17.7 & 0.9 & 8 & 5 & 0.9 & 8 & IL, PT, PG, PH & ST & $\mathrm{SF}$ \\
\hline Crepidula sp. & 9.0 & 1.5 & 8 & -16.3 & 0.7 & 8 & 4 & 1 & 8 & $\begin{array}{l}\mathrm{XH}, \mathrm{PT}, \mathrm{IL} \\
\mathrm{PG}, \mathrm{SW}\end{array}$ & IT, ST & GR \\
\hline Mytilus chilensis & 10.4 & 0.8 & 139 & -18.0 & 0.9 & 139 & 6 & 0.9 & 139 & $\begin{array}{l}\text { IL, PT, SW, } \\
\text { XH, PG, PH }\end{array}$ & IT, ST & $\mathrm{SF}$ \\
\hline Tegula sp. & 11.3 & 2.5 & 4 & -15.4 & 1.0 & 4 & 5 & 0.4 & 4 & $\mathrm{XH}, \mathrm{PT}, \mathrm{IL}, \mathrm{SW}$ & ST & GR \\
\hline Tunicata & & & & & & & & & & & & \\
\hline Synoicum sp. & 11.3 & & 1 & -19.7 & & 1 & 5 & & 1 & $\mathrm{PT}$ & ST & SF \\
\hline Arthropoda & & & & & & & & & & PH XH PT JU & & $\mathrm{SF}$ \\
\hline Elminius kingii & 12.2 & 1.1 & 12 & -17.6 & 1.2 & 12 & 5 & 1 & 12 & $\mathrm{PH}, \mathrm{XH}, \mathrm{PT}, \mathrm{IL}$ & IT & $\mathrm{SF}$ \\
\hline $\begin{array}{l}\text { Echinodermata } \\
\text { Arbacia dufresia }\end{array}$ & 7.8 & & 1 & -11.7 & & 1 & 10 & & 1 & $\mathrm{PH}$ & ST & GR \\
\hline
\end{tabular}


Table 1 (continued)

\begin{tabular}{|c|c|c|c|c|c|c|c|c|c|c|c|c|}
\hline Taxon & $\delta^{15} \mathrm{~N}$ & $\mathrm{SD}$ & $\mathrm{n}$ & $\delta^{13} \mathrm{C}$ & $\mathrm{SD}$ & $\mathrm{n}$ & $\mathrm{C} / \mathrm{N}$ & $\mathrm{SD}$ & $\mathrm{n}$ & Location & Depth & $\begin{array}{l}\text { Troph- } \\
\text { ism }\end{array}$ \\
\hline \multicolumn{13}{|l|}{ Teleostei } \\
\hline Small planktivorous fish & 14.2 & 0.4 & 3 & -16.0 & 1.9 & 3 & 4 & 0.3 & 3 & PT, PH, Muelle & & PV \\
\hline Eleginops maclovinus & 16.0 & 0.8 & 3 & -16.9 & 1.3 & 3 & 4 & 0.5 & 3 & XH, Caleta Leptepu & & $\mathrm{CV}$ \\
\hline Helicolenus lengerichi & 17.0 & 0.7 & 6 & -15.2 & 0.4 & 6 & 4 & 0.1 & 6 & $\mathrm{XH}, \mathrm{IL}, \mathrm{PG}, \mathrm{SW}$ & & $\mathrm{CV}$ \\
\hline Merluccius gayi & 19.4 & & 1 & -14.3 & & 1 & 4 & & 1 & $\mathrm{XH}$ & & $\mathrm{CV}$ \\
\hline Mugiloides chilensis & 16.3 & 2.2 & 2 & -16.5 & 2.4 & 2 & 4 & 0.0 & 2 & PH, PG & & $\mathrm{CV}$ \\
\hline Pinguipes chilensis & 15.8 & & 1 & -18.2 & & 1 & 6 & & 1 & $\mathrm{PH}$ & & $\mathrm{CV}$ \\
\hline Sebastes capensis & 16.7 & & 1 & -15.7 & & 1 & 4 & & 1 & $\mathrm{PH}$ & & $\mathrm{CV}$ \\
\hline \multicolumn{13}{|l|}{ Others } \\
\hline Faeces, sea lion & 18.2 & & 1 & -18.4 & & 1 & 8 & & 1 & Río Tambor & & \\
\hline Faeces, birds & 20.5 & 7.0 & 6 & -17.9 & 2.5 & 7 & 6 & 2 & 4 & $\mathrm{IL}, \mathrm{PT}$ & & \\
\hline $\begin{array}{l}\text { Plankton, seston } \\
\qquad(45-3000 \mu \mathrm{m} \text { size classes })\end{array}$ & 9.0 & 1.5 & 13 & -23.2 & 1.4 & 9 & 7 & 2 & 10 & $\begin{array}{l}\text { PT, PH, SW, IL, } \\
\text { Huinay station }\end{array}$ & & \\
\hline Soil, peat & 0.7 & 2.4 & 10 & -27.9 & 1.0 & 7 & 22 & 7 & 8 & Catchment & & \\
\hline Terrestrial plants & -4.2 & 5.7 & 29 & -29.3 & 3.0 & 23 & 61 & 41 & 29 & Catchment & & \\
\hline
\end{tabular}

marine primary producers were highly variable. The lowest marine $\delta^{15} \mathrm{~N}$ value $(-0.3 \%$ ) was recorded for cyanobacteria growing in the intertidal zone. Average values for various macroalgal taxa ranged from $4.9 \%$ for the chlorophyte Rhizoclonium sp. to $12.6 \%$ for the rhodophyte Porphyra columbina (Fig. 3). The $\delta^{15} \mathrm{~N}$ values of grazers (gastropods Tegula sp. and Crepidula sp.) sampled at several locations also showed increased $\delta^{15} \mathrm{~N}$ variability $(11.3 \pm 2.5$ and 9.0 $\pm 1.5 \%$, respectively) and exhibited values still in the range of those of some primary producers. The $\delta^{15} \mathrm{~N}$ values of suspension feeders included a single value for tunicates $(11.3 \%$ ) and replicated data between $10.4 \pm 0.8 \%$ (Mytilidae) and $14.5 \pm$ $0.8 \%$ (Desmophyllum dianthus) for other groups. The 6 species of carnivorous fish had the highest $\delta^{15} \mathrm{~N}$ values. All fish $\delta^{15} \mathrm{~N}$ values clustered between 17.0 and $15.8 \%$, except that of Merluccius gayi, which provided the highest animal tissue value $(19.4 \%$ o) in the dataset.

With respect to $\delta^{13} \mathrm{C}$ values, marine organisms can be separated into 2 main groups. Some rhodophyte taxa (Bostrychia radicans, Griffithsia chilensis, Gigartina skottsbergii, Rhodymenia howeana, Schizoseris dichotoma) showed extraordinary negative $\delta^{13} \mathrm{C}$ values ranging between -23.4 and $-31.3 \%$ on average. All other taxa had $\delta^{13} \mathrm{C}$ values ranging between $-9.3 \%$ (cyanobacteria) and $-18.8 \%$ (Ulothrix sp.). Chlorophytes, other rhodophytes and phaeophytes had average $\delta^{13} \mathrm{C}$ values from -11.9\% (Rhizoclonium sp.) to $-19.5 \%$ (Halopteris funicularis).

A likely cause for the observed isotopic variability for some organism groups (e.g. macroalgae) in Comau Fjord is the differential influx of nutrients and terrestrial organic matter (TOM) brought into the fjord primarily via rivers. Representative samples of TOM, such as soils and plants, were collected in the catchment (Table 1). Terrestrial plants and soils had more negative $\delta^{13} \mathrm{C}$ values $(-29.3$ and $-27.9 \%$ on
Fig. 3. $\delta^{13} \mathrm{C}$ versus $\delta^{15} \mathrm{~N}$ values of different organisms from Comau Fjord. Each symbol represents a taxon. Error bars represent $1 \mathrm{SD}$ for replicate analyses from different individuals ( $\mathrm{n}=3$ to 48 ) or absolute differences $(\mathrm{n}=2)$; error bars are missing for taxa without replicate analyses. Filled symbols: taxonomic groups of macroalgae; open symbols: different feeding types of animals. See Table 1 for more details 
average, respectively) than all other marine organisms, except for the aforementioned rhodophyte taxa, which had similarly low values (Table 1 ). The $\delta^{15} \mathrm{~N}$ values of terrestrial plants and soils were also much more negative (means: -4.2 and $0.7 \%$, respectively) than those of all other marine organic tissues, except for cyanobacteria. Other potential nutrient sources of local importance were faeces from the bird and sea lion colonies at Isla Liliguapi. The $\delta^{15} \mathrm{~N}$ values of bird faeces were $20.5 \%$ on average, and a single sample of sea lion excrement was 18.2\%. Some of these samples provided the highest $\delta^{15} \mathrm{~N}$ values in the dataset.

The sampling locations of marine organisms were chosen along vertical and horizontal salinity gradients in the fjord. The 2 benthic organism groups, macroalgae and Mytilidae, were best suited for the present study, because they occur frequently at every depth at all 6 sampling locations.

\section{Spatial isotopic variability of macroalgae}

Differences of up to $8 \%$ were recorded for individuals of the most common chlorophyte genera, Enteromorpha (absolute range between 13.1 and 4.8\%o) and Ulva (range between 13.8 and 6.3\%o), collected at different locations and depths. For practical reasons, we used the taxonomic classification based on phenotypes here and not the molecular system suggested by Hayden et al. (2003), which merges Ulva and Enteromorpha into a single genus, Ulva. $\mathrm{N}$ content and $\delta^{15} \mathrm{~N}$ values were significantly correlated for these 2 genera (Spearman rank-order correlation, 2-tailed, $\mathrm{r}_{\mathrm{s}}=0.76$, $\mathrm{p}<0.0001, \mathrm{n}=88$ ), suggesting differential nutritional conditions as a likely cause for $\delta^{15} \mathrm{~N}$ variability. The $\delta^{15} \mathrm{~N}$ values increased with increasing $\mathrm{N}$ content in these macroalgal taxa (Fig. 4). The lowest $\mathrm{N}$ contents (0.4 to $1.2 \%$ ) and the highest $\mathrm{C} / \mathrm{N}$ ratios (29 to 93) came from chlorophytes of the most freshwater-influenced site Punta Huinay (Fig. 5). In contrast, the highest $\mathrm{N}$ contents (>3\%) and the lowest $\mathrm{C} / \mathrm{N}$ ratios (all $<11$ with 1 exception) belonged to samples from the most openmarine site, Isla Liliguapi (Fig. 5).

Since Enteromorpha and Ulva were not present at all sites and depths, the $\delta^{15} \mathrm{~N}$ values of all macroalgae were sorted according to depth, to evaluate whether there is an isotope shift on a bathymetric scale as well (Fig. 6). The mean $\delta^{15} \mathrm{~N}$ values of macroalgae from the high intertidal differed by up to $8 \%$. Values of around
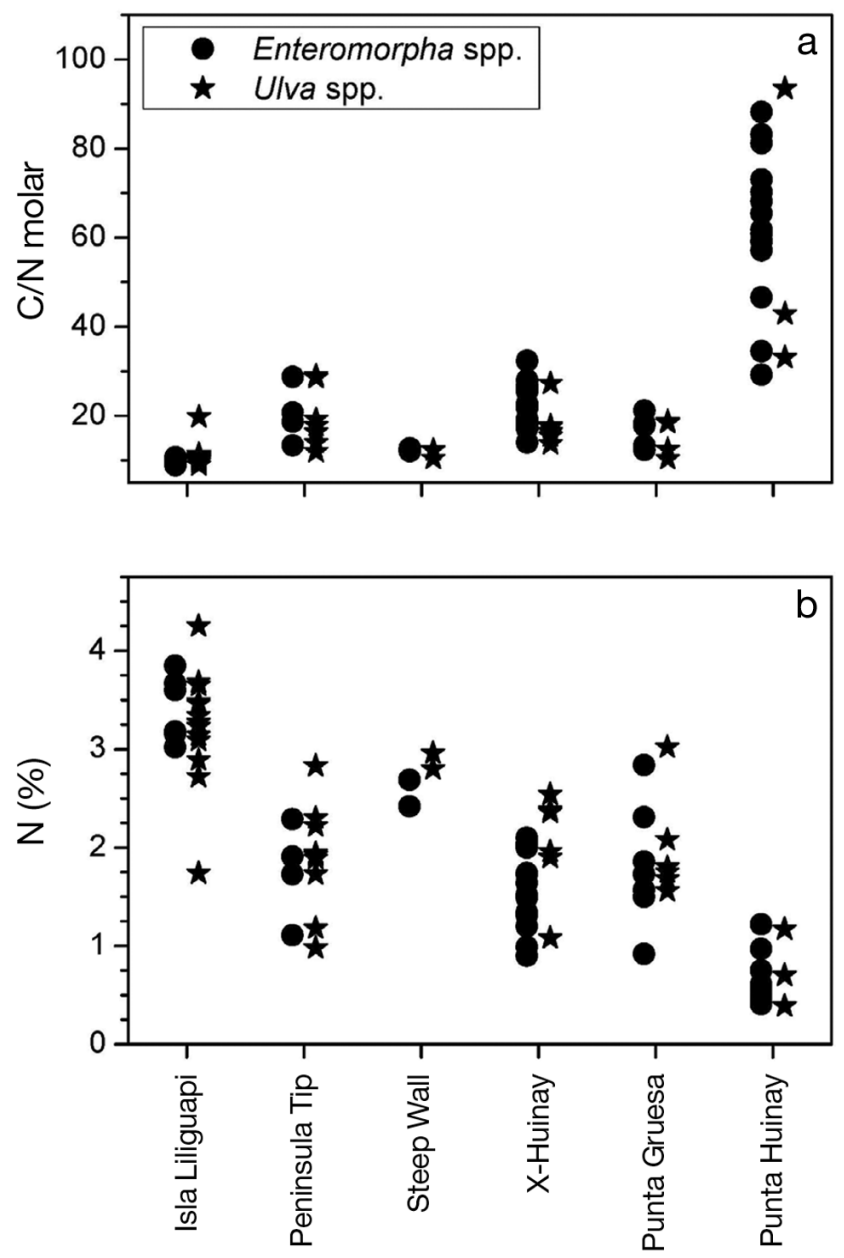

Fig. 5. (a) $\mathrm{C} / \mathrm{N}$ ratios and (b) $\mathrm{N}$ weight-percentages for Enteromorpha spp. and Ulva spp. sorted by location 


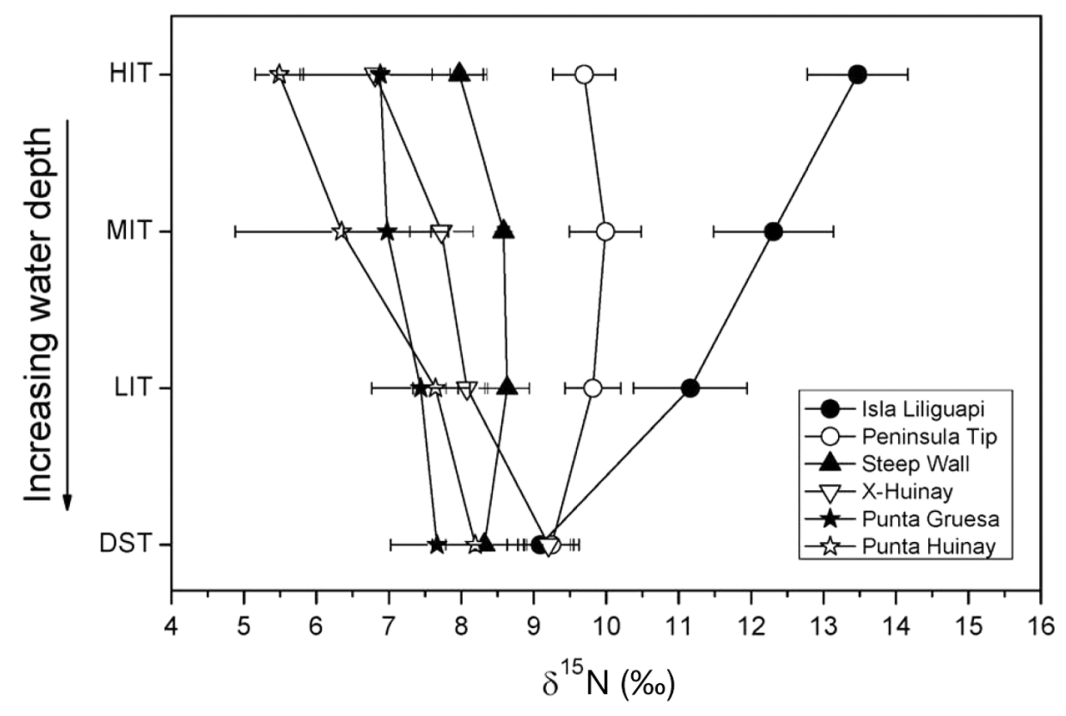

Fig. 6. $\delta^{15} \mathrm{~N}$ values of all macroalgae versus depth at the 6 sampling locations. HIT, MIT, LIT: high, mid-, low intertidal, respectively; DST: deeper subtidal. Error bars represent $1 \mathrm{SD}$ for 3 to 8 specimens or absolute differences $(\mathrm{n}=2)$ at each depth

$5.5 \%$ occurred at Punta Huinay in the intertidal zone. With increasing distance to the riverine inflows and increasing proximity to the mouth of the fjord, $\delta^{15} \mathrm{~N}$ values increased in the intertidal. At the mainland site closest to the fjord mouth (Peninsula Tip), no significant isotopic change was observed with increasing depth (Kruskal-Wallis test, $\mathrm{p}=0.280$ ). The site Isla Liliguapi provided exceptionally high $\delta^{15} \mathrm{~N}$ values in the high intertidal $(13.5 \%)$. The samples were taken in 2 different seasons (June and October 2007) and showed the same pattern in both periods (Table 2). With increasing depth, the isotopic differences between the sites diminished. In the deep subtidal, the $\delta^{15} \mathrm{~N}$ values only varied between 7.7 and $9.3 \%$.

\section{Spatial isotopic variability of Mytilidae}

Apparently, neither species affiliation (Mytilus chilensis and Aulacomya ater) nor shell length had an influ-

Table 2. $\delta^{15} \mathrm{~N}$ values for macroalgae from Isla Liliguapi, as an example of homogeneity of isotope data collected in 2 different periods (June and October 2007). HIT, MIT, LIT: high, mid-, low intertidal, respectively

\begin{tabular}{|c|c|c|c|c|c|c|}
\hline \multirow{2}{*}{$\begin{array}{l}\text { Depth } \\
\text { zone }\end{array}$} & \multicolumn{3}{|c|}{-28 Jun $2007-$} & \multicolumn{3}{|c|}{-18 Oct 2007} \\
\hline & $\delta^{15} \mathrm{~N}(\%)$ & $\mathrm{SD}$ & $\mathrm{n}$ & $\delta^{15} \mathrm{~N}(\%)$ & $\mathrm{SD}$ & $\mathrm{n}$ \\
\hline HIT & 13.9 & 0.9 & 3 & 13.2 & 0.4 & 4 \\
\hline MIT & 12.4 & 1.1 & 3 & 12.2 & 0.7 & 4 \\
\hline LIT & 10.7 & 1.1 & 3 & 11.5 & 0.4 & 4 \\
\hline
\end{tabular}

ence on $\delta^{15} \mathrm{~N}$ values of the sampled mytilids, as shown exemplary for Punta Gruesa, where the greatest number of mytilid isotope data were available (Fig. 7). Therefore, the $\delta^{15} \mathrm{~N}$ data for all Mytilidae were evaluated together. Site and water depth had an influence on the $\delta^{15} \mathrm{~N}$ values of Mytilidae, but much less so than for macroalgae (Fig. 8). Similar to macroalgae, mytilids had the lowest $\delta^{15} \mathrm{~N}$ values $(9.0 \%$ ) in the intertidal (Punta Huinay) and they were most ${ }^{15} \mathrm{~N}$-enriched at Isla Liliguapi (11.5\%). Although the differences between the 2 extreme sites were statistically significant (MannWhitney $U$-test, 2-tailed, $\mathrm{p}=0.003$ ), the isotopic discrepancy of $2.5 \%$ was much lower than that for the intertidal macroalgae at the same sites (8\% difference). Similar to macroalgae, the Mytilidae displayed a convergence of $\delta^{15} \mathrm{~N}$ values with increasing depth. In the subtidal, the average $\delta^{15} \mathrm{~N}$ values were almost indistinguishable between the sites and ranged between 10.7\%o (Punta Huinay) and 11.4\%o (Steep Wall).

\section{$\delta^{15} \mathrm{~N}$ of suspension feeders and seston fractions}

Large $\delta^{15} \mathrm{~N}$ differences occurred between the groups of suspension feeders (Fig. 9). Together with the single tunicate sample analysed, the Mytilidae had the lowest $\delta^{15} \mathrm{~N}$ values among this feeding-type group (10.4 \pm $0.8 \%$ ). The balanid Elminius kingii had about $1.7 \%$ higher average values than mytilids $(12.1 \pm 1.9 \%$ and $12.2 \pm 1.1 \%$, respectively). The gorgonian Primnoella chilensis had $\delta^{15} \mathrm{~N}$ values of $13.3 \pm 0.6 \%$. The highest

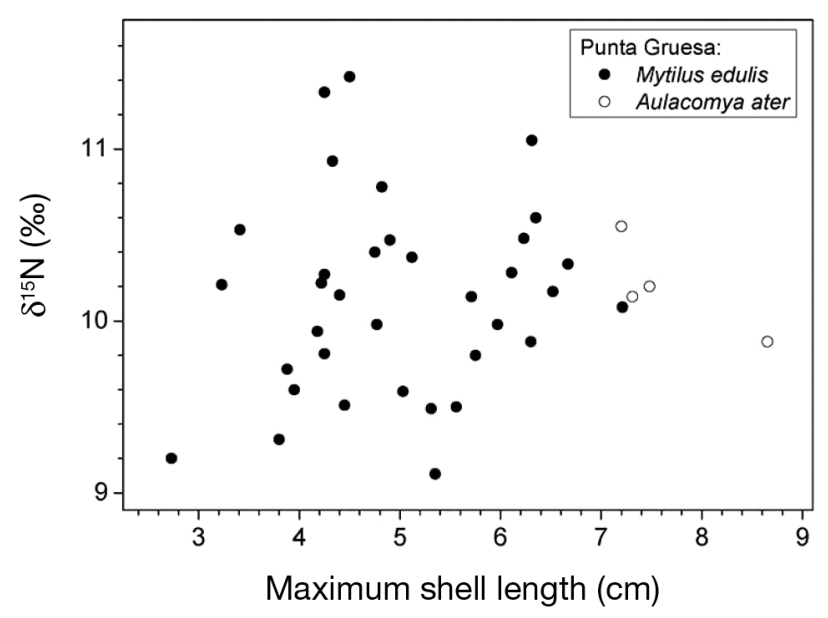

Fig. 7. $\delta^{15} \mathrm{~N}$ values of Mytilus chilensis and Aulacomya ater from Punta Gruesa versus maximum shell length 


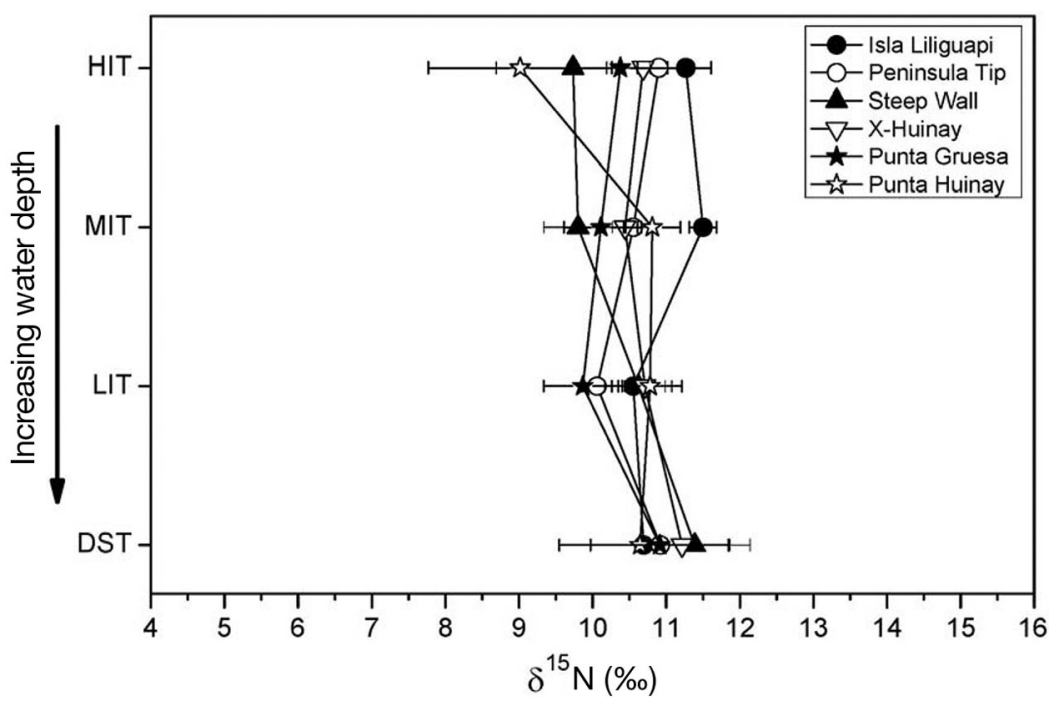

Fig. 8. $\delta^{15} \mathrm{~N}$ values of all Mytilidae versus depth (see Fig. 6 for depth abbreviations) at the 6 sampling locations. Error bars represent 1 SD for 3 to 14 specimens or absolute differences $(\mathrm{n}=2)$ at each depth. DST samples from Peninsula Tip, Punta Huinay and X-Huinay are only represented by 1 individual

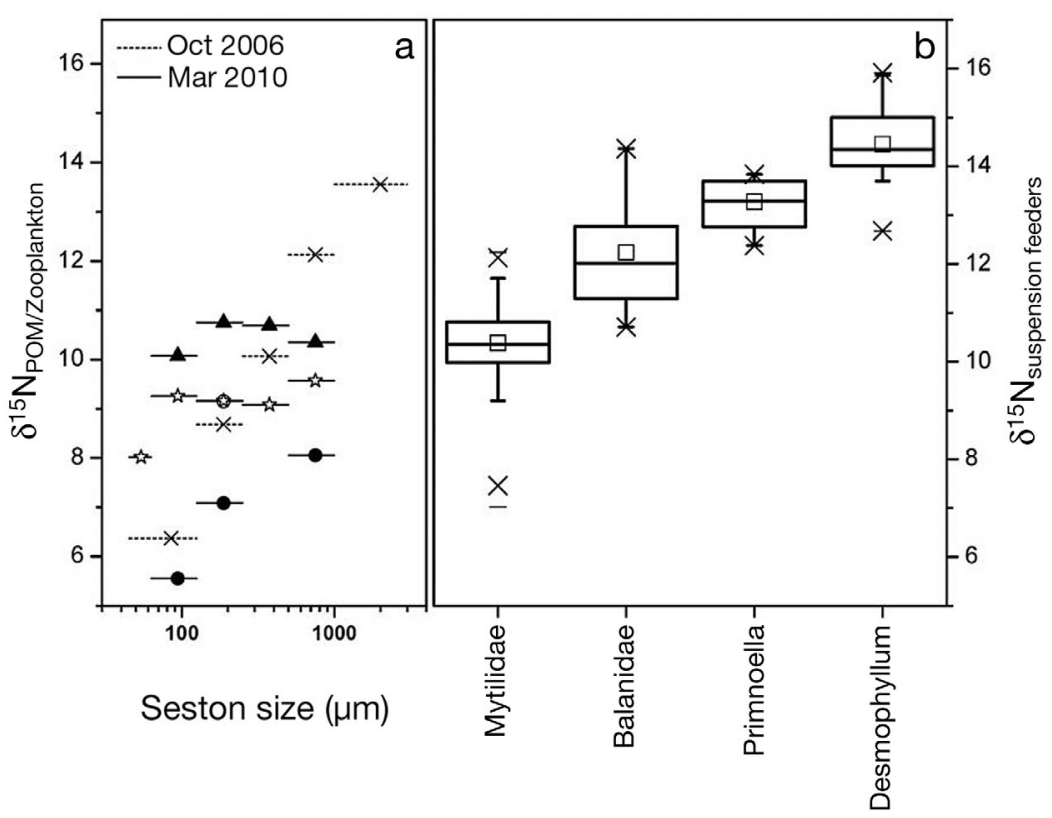

Fig. 9. $\delta^{15} \mathrm{~N}$ values of (a) seston samples of different size classes compared to (b) box-and-whisker plots of $\delta^{15} \mathrm{~N}$ values of selected suspension feeders. Symbols in (a) are as in Fig. 8 ( $\times$ : additional samples from Huinay station). Bars show size classes of the sieved samples. (b) Box limits represent 25th and 75th percentiles and whiskers represent 5th and 95th percentiles. Means are represented by squares, and medians by solid lines. Crosses mark the 1 and $99 \%$ ranges, and short lines the maxima and minima of the distributions

values for suspension feeders were observed for the scleractinian coral Desmophyllum dianthus (14.6 \pm $0.8 \%$ ). Overall, the nitrogen isotopic signatures of suspension feeders, excluding sponges, covered a range of $>4 \%$. The few Porifera data available exhibited a remarkable range of $5.2 \%$ within this group (Table 1). The lowest $\delta^{15} \mathrm{~N}$ values occurred in Callyspongia sp. $(10.7 \%)$, and the highest in Dramacidon egregia $(15.9 \%)$.

Seston of different size fractions was analysed to evaluate whether there is a size effect on the isotopic composition of seston suspended in the water column. The samples in October 2006 were taken in front of the Huinay research station, between Punta Huinay and Punta Gruesa, and showed a clear trend of increasing $\delta^{15} \mathrm{~N}$ values with increasing particle size (Fig. 8). The seston samples from March 2010 varied greatly among sites and exhibited size dependency, especially at the site Isla Liliguapi, whereas size fractions between 63 and $1000 \mu \mathrm{m}$ were isotopically similar at Punta Huinay and Steep Wall (Fig. 9). Microscopic inspection of these samples showed that they consisted mainly of phytoplankton (mainly diatoms), with varying contributions of zooplankton organisms (copepods, crustacean larvae).

\section{DISCUSSION}

\section{Carbon sources for primary producers}

The macroalgae from Comau Fjord exhibit a wide range of $\delta^{13} \mathrm{C}$ and $\delta^{15} \mathrm{~N}$ values. Very negative $\delta^{13} \mathrm{C}$ values $(-23$ to $-31 \%$ o) separate 5 rhodophyte taxa from all the other rhodophytes, phaeophytes and chlorophytes. Large $\delta^{13} \mathrm{C}$ differences between algae were related to their differential ability to use bicarbonate $\left(\mathrm{HCO}_{3}^{-}\right)$for photosynthesis (Keeley \& Sandquist 1992, Maberly et al. 1992). The basic reason for this discrepancy is the isotopic difference between the assimilated dissolved inorganic carbon (DIC) sources, i.e. the carbon isotope fractionation between dissolved $\mathrm{CO}_{2}$ and bicarbonate (Mook et al. 1974). According to physiological models, $\mathrm{CO}_{2}$-restricted aquatic plants produce organic matter with $\delta^{13} \mathrm{C}$ values potentially ranging between -11 and $-40 \%$ when dissolved $\mathrm{CO}_{2}$ is taken up, whereas $\mathrm{HCO}_{3}{ }^{-}$users typically 
have values between -11 and $-21 \%$ o (Maberly et al. 1992). Accordingly, the 5 rhodophyte taxa exhibiting very negative values are not able to assimilate $\mathrm{HCO}_{3}{ }^{-}$ and belong to those algae restricted to $\mathrm{CO}_{2}$ uptake. All other taxa use $\mathrm{HCO}_{3}{ }^{-}$, the predominant DIC species under normal marine conditions (Sarmiento \& Gruber 2006).

\section{Nitrogen sources and availability for primary producers}

Nitrogen availability affects the $\delta^{15} \mathrm{~N}$ values of bacteria and plants due to kinetic fractionation effects during $\mathrm{N}$ assimilation following a Rayleigh-type pattern of isotope fractionation (Mariotti et al. 1981, Evans 2001). According to the model, the ${ }^{15} \mathrm{~N}$ content of biomass produced at a given time in a closed system increases in an exponential way with decreasing nutrient availability when the nutrient reservoir is not replenished. The $\delta^{15} \mathrm{~N}$ value of the total biomass after complete nutrient consumption, however, must equal that of the nutrient reservoir at the beginning. In contrast, in a steady state system with a constant rate of nutrient supply, the $\delta^{15} \mathrm{~N}$ values of primary producers should linearly increase with increasing bioproductivity. Although in natural systems neither bioproductivity nor fluxes of nutrients nor biomass loss by consumption and sedimentation will be constant, an increase in bioproductivity will, in all cases, lead to ${ }^{15} \mathrm{~N}$-enriched, instantaneously produced biomass with decreasing $\mathrm{N}$ availability. For phytoplankton, this pattern of isotope fractionation due to varying nutrient concentrations has been observed in experiments (Waser et al. 1998) and in field studies (e.g. Cifuentes et al. 1988, Goering et al. 1990). Our seston isotope data also showed great spatio-temporal variability that is likely linked to nutrient consumption and availability (Fig. 9).

Whereas phytoplanktonic $\delta^{15} \mathrm{~N}$ is strongly affected by both the isotopic signature of DIN and isotopic fractionation due to changing nutrient conditions, the macroalgal $\delta^{15} \mathrm{~N}$ values from Comau Fjord showed no such large $\delta^{15} \mathrm{~N}$ variability and no trends related to nutrient depletion, but likely reflected isotopic variations in DIN. As an example, macroalgae collected at different seasons (June and October 2007) at the same depths at Isla Liliguapi showed very similar $\delta^{15} \mathrm{~N}$ values (Table 2), suggesting that seasonal $\delta^{15} \mathrm{~N}$ variability is small compared to regional differences. In experiments with the macroalga Enteromorpha intestinalis, no $\delta^{15} \mathrm{~N}$ response to varying nitrate and ammonium concentrations was found, and, therefore, it was concluded that DIN concentration does not have an influence on $\delta^{15} \mathrm{~N}$ values of that macroalgal taxon (Cohen \& Fong 2005). In further experiments, isotopically differ- ing DIN (ammonium and nitrate) sources were reliably reflected in the $\delta^{15} \mathrm{~N}$ values of marine macroalgae (Cohen \& Fong 2005). Thus, macroalgal $\delta^{15} \mathrm{~N}$ values can successfully be used to trace isotopically distinguishable DIN inputs, like sewage plumes and aquacultural fish excretions, into marine habitats (e.g. Costanzo et al. 2001, Rogers 2003, García-Sanz et al. 2010). In cases of anthropogenic sewage input, microbial processes such as denitrification can become important (Savage \& Elmgren 2004), because these processes alter the DIN isotopic composition substantially (Mariotti et al. 1981). However, substantial denitrification due to sewage effluents can be excluded in the sparsely populated area of Comau Fjord. Less isotopic evidence is available that macroalgal $\delta^{15} \mathrm{~N}$ values are influenced by non-anthropogenic, terrestrial DIN sources in coastal habitats. An inverse linear or curvilinear correlation between macroalgal $\delta^{15} \mathrm{~N}$ values and distance from the shore was observed in coastal habitats off the Ryuku Islands, Japan, and related to terrestrial DIN sources (Umezawa et al. 2002). $\delta^{15} \mathrm{~N}$ values obtained from the macroalga Ulva pertusa in the fjord Doubtful Sound, New Zealand, exhibited similar isotope patterns as those observed for the macroalgae from Comau Fjord (Cornelisen et al. 2007). In their study, macroalgal $\delta^{15} \mathrm{~N}$ values also increased along the fjord axis from the head to the mouth of the fjord as well as with water depth. Cornelisen et al. (2007) showed in experimental approaches and with field observations that other factors were of minor importance (irradiance gradients) or negligible (seasonal changes in irradiance, water velocity) for the nitrogen isotope composition of $U$. pertusa and concluded that the source pool signature is the most prominent influencing factor for macroalgal $\delta^{15} \mathrm{~N}$ variation.

Thus, the observed macroalgal $\delta^{15} \mathrm{~N}$ increase from river inflows to the fjord mouth can be related to differential DIN sources in the intertidal. Terrestrial organic matter (soils and plants) from the fjord catchment typically have lower $\delta^{15} \mathrm{~N}$ values (averages: 0.7 and $-4.2 \%$, respectively; Table 1) than the marine organic matter from Comau Fjord. DIN derived from terrestrial sources is expected to have low $\delta^{15} \mathrm{~N}$ values (Natelhoffer \& Fry 1988), in contrast to open-marine nitrate, which has a $\delta^{15} \mathrm{~N}$ value of ca. $9.5 \%$ in the south-eastern Pacific Ocean at latitude $50^{\circ}$ (Sigman et al. 1999). Isotopic composition of DIN sources in the fjord, therefore, is expected to be determined by a 2-end-member mixing system consisting of relatively ${ }^{15} \mathrm{~N}$-poor terrestrial DIN sources (river inflows) and ${ }^{15} \mathrm{~N}$-rich openmarine DIN sources advected through the oceanic entrance. Mixing of these 2 sources can explain both lateral and vertical $\delta^{15} \mathrm{~N}$ variability of macroalgae at all sites, except Isla Liliguapi. The increasing intertidal macroalgal $\delta^{15} \mathrm{~N}$ values from Punta Huinay towards 
Peninsula Tip (Fig. 6) demonstrate a decreasing influence of terrestrial ${ }^{15} \mathrm{~N}$-poor DIN sources. $\delta^{15} \mathrm{~N}$ values increasing with depth at the most freshwaterinfluenced site, Punta Huinay, demonstrate diminishing influence of the freshwater DIN pool with depth towards the subtidal.

The ${ }^{15} \mathrm{~N}$-enriched intertidal values of macroalgae at Isla Liliguapi, however, cannot be explained by a 2-source mixture between terrestrial and open-marine DIN sources. A third highly ${ }^{15} \mathrm{~N}$-enriched DIN source has to be postulated there. The bird and sea lion population on the island provide this additional nitrogen source. Their faeces have extremely ${ }^{15} \mathrm{~N}$-enriched values (averages: 20.5 and 18.2\%, respectively; Table 1). Such high $\delta^{15} \mathrm{~N}$ values have been reported from soils in sea animal colonies in Antarctica (Zhu et al. 2008). These soils are derived from the faeces of animals from the uppermost trophic levels (penguins, skuas and seals) and have $\delta^{15} \mathrm{~N}$ values of 12.6 to $18.8 \%$ or total nitrogen, similar or somewhat lower than those of the bird and sea lion faeces at Isla Liliguapi. The $\delta^{15} \mathrm{~N}$ values of $\mathrm{NO}_{3}{ }^{-}$and $\mathrm{NH}_{4}{ }^{+}$in those Antarctic soils were 10.2 to 13.9 and 20.3 to $22.8 \%$, respectively (Zhu et al. 2008). Thus, nitrate and ammonium inputs from the ${ }^{15} \mathrm{~N}$-enriched DIN sources of the animal colonies at Isla Liliguapi best explain the elevated $\delta^{15} \mathrm{~N}$ values of intertidal macroalgae around the island.

Mixing of different nutrient sources can also go along with differential nutrient availability for benthic primary producers due to additive or dilution effects. Previous studies demonstrated that $\mathrm{N}$ availability is reflected in the $\mathrm{N}$ content and $\mathrm{C} / \mathrm{N}$ ratios of macroalgal tissues (Thompson \& Valiela 1999, Savage \& Elmgren 2004). Whereas the molar $\mathrm{C} / \mathrm{N}$ ratio of phytoplankton is commonly close to the Redfield ratio (i.e. around 7; Redfield et al. 1963, Anderson \& Sarmiento 1994), the $\mathrm{C} / \mathrm{N}$ ratio in benthic macroalgae is higher and more variable due to a higher structural $\mathrm{C}$ content or due to $\mathrm{N}$ limitation (Garrison et al. 2007). Experiments have shown that Enteromorpha intestinalis is capable of storing nitrate and (to a lesser extent) ammonium in its tissues (Cohen \& Fong 2005). N storage in macroalgal tissue results in a lowering of the $\mathrm{C} / \mathrm{N}$ ratios. The $\mathrm{C} / \mathrm{N}$ range, between 9 and 93, of the macroalgae Ulva spp. and Enteromorpha spp. from Comau Fjord (Fig. 5) is large compared to the macroalgal $\mathrm{C} / \mathrm{N}$ ratios, between 14 and 28, reported in other studies for various marine species (Lapointe et al. 1992, Umezawa et al. 2002); this was interpreted in terms of differential $\mathrm{N}$ availability along a nutrient gradient in a Baltic Sea bay (Savage \& Elmgren 2004). Accordingly, the highest $\mathrm{C} / \mathrm{N}$ ratios occur at Punta Huinay and coincide with the lowest $\mathrm{N}$ content in the tissue (Fig. 5), indicating that these algae grew at the site with the most N-limiting conditions.
The available nitrate concentration data (Fig. 2) show no major differences in concentrations between the sites, but the data are sparse and only represent a momentary picture of the nutrient situation. Macroalgal $\mathrm{N}$ contents reflect the integrated $\mathrm{N}$ availability over their growth period (Savage \& Elmgren 2004) and, thus, likely reflect overall nutrient availability more reliably than a few short-term nitrate analyses. The $\mathrm{N}$ limitation near the mouth of the river suggested by our macroalgal data is supported by studies of DIN efflux from regional Chilean forest ecosystems. DIN efflux from unpolluted old-growth forests in Chile is very low ( 0.5 to $18 \mu \mathrm{g} \mathrm{N}^{-1}$ ) compared to e.g. North American temperate forests (350 to $766 \mu \mathrm{g} \mathrm{N}$ $\mathrm{l}^{-1}$ ), and most of the $\mathrm{N}$ export from such forested ecosystems occurs as dissolved organic nitrogen (Perakis \& Hedin 2002). Dissolved organic nitrogen has to be remineralised before it can be taken up by primary producers and thus is not available to the macroalgae in the fjord instantaneously. Consequently, high freshwater influx into the fjord does not necessarily increase DIN availability, but rather dilutes the DIN from marine sources without balancing the nitrogen budget. These considerations are in accordance with the low $\mathrm{N}$ contents, high $\mathrm{C} / \mathrm{N}$ ratios and low $\delta^{15} \mathrm{~N}$ values of macroalgae at Punta Huinay reflecting an additional, terrestrial nitrogen source, but N-limiting conditions. In contrast, the high $\mathrm{N}$ contents and low $\mathrm{C} / \mathrm{N}$ ratios of Ulva spp. and Enteromorpha spp. from Isla Liliguapi (Fig. 5) point to an additional nutrient source via faeces from high trophic level animals, increasing the intertidal nitrogen budget there. Macroalgae at all other sites show $\mathrm{C} / \mathrm{N}$ ratios and $\mathrm{N} \%$ values intermediate between the 2 extremes and exhibit an average signal comparable to macroalgae from other estuarine and coastal areas (Lapointe et al. 1992, Umezawa et al. 2002, Kamer et al. 2004).

\section{Implications for food web}

The heavy isotopic enrichment between an animal and its food is about $1 \%$ for $\delta^{13} \mathrm{C}$ and about $3.4 \%$ for $\delta^{15} \mathrm{~N}$ (DeNiro \& Epstein 1981, Minagawa \& Wada 1984, Peterson \& Fry 1987). Due to the smaller isotopic fractionation, $\delta^{13} \mathrm{C}$ is only suitable for distinguishing the food sources of animals, if these have large isotopic differences (Hill \& McQuaid 2008). This is the case for the benthic macroalgae from Comau Fjord, which are divided into $\mathrm{HCO}_{3}{ }^{-}$-using macroalgae and a few $\mathrm{CO}_{2}$ users belonging to rhodophytes with very low $\delta^{13} \mathrm{C}$ values (below -23\%). A major contribution of these rhodophyte taxa to the food of the investigated animals can be excluded, however, as all examined animals are in the range of the $\mathrm{HCO}_{3}^{-}$users (Fig. 3). 
The $\delta^{15} \mathrm{~N}$ values allow further distinction of food sources. Trophic nitrogen isotope enrichment between animals and their food is, to a certain degree, variable and depends on the biochemical form of nitrogen excretion and on nutritional status (Vanderklift \& Ponsard 2003). Moreover, reported fractionation values for mytilids differ greatly. Bode et al. (2006) used an average value of $1.4 \%{ }^{15} \mathrm{~N}$ enrichment between food sources and consumers (among them Mytilus galloprovincialis) and suggested a prevalence of omnivory in their food webs. In contrast, feeding experiments with $M$. edulis provided a higher value (3.8\%) of species-specific ${ }^{15} \mathrm{~N}$ enrichment (Dubois et al. 2007) close to that commonly used (3.4\%; e.g. Post 2002). Using the isotope enrichment of Dubois et al. (2007), the food of Mytilidae from Comau Fjord had an average $\delta^{15} \mathrm{~N}$ value of $6.6 \%$, and the calculated value of Mytilidae food agrees best with the low $\delta^{15} \mathrm{~N}$ values of small-sized seston (Fig. 9). If the trophic isotope enrichment of Bode et al. (2006) is assumed, the mytilid food is represented by seston with $\delta^{15} \mathrm{~N}$ values around $9 \%$ and overall larger seston particle size. The large temporal $\delta^{15} \mathrm{~N}$ variability of plankton, e.g. during blooms (Goering et al. 1990) or starvation periods (Waser et al. 1999), is also reflected in the spatio-temporal variability of seston $\delta^{15} \mathrm{~N}$ values in our study. As this variability is not reflected in their isotopic composition, it is reasonable to assume that mytilids in Comau Fjord, as well as other filter feeders, show the integrated isotopic signature of their food in time.

${ }^{15} \mathrm{~N}$ enrichment with increasing size class of particulate organic matter (POM) has already been determined in previous studies (Altabet 1988, Rau et al. 1990). Rau et al. (1990) observed differences of up to $5 \%$ between different POM size classes from a coastal Mediterranean site. The lowest $\delta^{15} \mathrm{~N}$ values were related to nano- and picoplankton, and higher values, to larger particles, independent of season (Rau et al. 1990). Although the particle size classes in our study do not include size fractions $<45 \mu \mathrm{m}$, the overall data show, in addition to spatio-temporal variability, a $\delta^{15} \mathrm{~N}$ increase with increasing particle size (Fig. 9). Differences between $\delta^{15} \mathrm{~N}$ values of suspension feeders in Comau Fjord may, thus, point to food specialisation on different seston size classes. Although Mytilus edulis was found to be a non-selective filter feeder that effectively filters all particles $>2$ to $5 \mu \mathrm{m}$ (Widdows et al. 1979), previous isotope studies also demonstrated that the main food source of mytilids is phytoplankton, whereas TOM, macroalgal detritus, or benthic microalgae play only a minor role, if any (Riera et al. 1999, Dubois et al. 2007).

In contrast to the phytoplankton-filtering Mytilidae, the octocoral Primnoella sp. has a $3.2 \%$ higher $\delta^{15} \mathrm{~N}$ value, which would indicate that it consumes food of a higher trophic level. In experiments, however, Antarctic Primnoella specimens fed primarily on small-plankton communities and ingested little zooplankton (Orejas et al. 2003). The $\delta^{15} \mathrm{~N}$ values of Primnoella sp. from Comau Fjord point to a main food source with an isotopic composition in the range of the 100-1000 $\mu \mathrm{m}$ seston size fraction (Fig. 9). Balanidae have $\delta^{15} \mathrm{~N}$ values between Primnoella sp. and Mytilidae, possibly implying a mixture of phyto- and zooplankton as their food. The highest $\delta^{15} \mathrm{~N}$ values $(14.5 \%$ ) of all investigated suspension feeders are those of the scleractinian coral Desmophyllum dianthus. This high value suggests that the food of $D$. dianthus is derived partly from particles of higher trophic levels than that of Primnoella sp. and thus possibly from the largest size fractions of seston. The discrepancies between suspension feeders may thus indicate selective filtering of food with differential isotopic composition. The total $\delta^{15} \mathrm{~N}$ range between the various suspension-feeding taxa is $4 \%$ (Fig. 9). This corresponds to $>1$ trophic level and is not explained by spatial isotope variability of food sources, as the relatively uniform $\delta^{15} \mathrm{~N}$ values of the mytilids at the various sampling locations demonstrate (Fig. 8). To summarise, preference for specific size classes of marine POM as food would best explain $\delta^{15} \mathrm{~N}$ variability among benthic suspension feeders, except for sponges.

The generally wide range of the few sponge $\delta^{15} \mathrm{~N}$ values, and especially the extremely high value of Dramacidon egregia, cannot be attributed to trophic ${ }^{15} \mathrm{~N}$ enrichment. However, sponges are known to host a variety of microorganisms (Wilkinson 1978), and some taxa supply nitrogen to their hosts (Davy et al. 2002). Microbial processes can also influence the $\delta^{15} \mathrm{~N}$ signatures of sponges (Weisz et al. 2007, Southwell et al. 2008). Although large $\delta^{15} \mathrm{~N}$ variability is already visible in the presently available sponge dataset from Comau Fjord, more systematic investigations are necessary in the future to decipher the processes behind this pattern.

\section{Implications for the $\mathrm{C}$ - and $\mathrm{N}$-cycles}

The isotope data from Comau Fjord suggest that, on the one hand, terrestrial DIN sources are taken up by benthic macroalgae close to the mouths of rivers, and, on the other hand, terrigenous POM is not an important food source for benthic filter feeders attached to hard-ground environments. Although a variety of isotopic studies deal with riverine inflow into estuarine and coastal environments (e.g. Rogers 2003, Fertig et al. 2009), most of them are aimed at detecting anthropogenic sources, such as sewage inflows, which can be distinguished from unpolluted marine sources via their $\delta^{15} \mathrm{~N}$ values (Heaton 1986, Costanzo et al. 2001). How- 
ever, in the sparsely populated area of Comau Fjord sewage inflow can be neglected. Biogeographic trends along a $1400 \mathrm{~km}$ long South African coast transect demonstrated different nitrogen sources influencing $\delta^{15} \mathrm{~N}$ and $\delta^{13} \mathrm{C}$ signatures of consumers on rocky intertidal habitats (Hill \& McQuaid 2008). Even coastal areas with relatively high anthropogenic influence show a predominance of phytoplanktonic organic matter in the food of benthic filter feeders (Page \& Lastra 2003). Carbon and nitrogen isotope signatures of organisms from an estuarine food web in Plum Island Sound, USA, also exhibited minimal importance of TOM (Deegan \& Garritt 1997). This corresponds with our results from benthic filter feeders exhibiting little isotopic variance, although the reasons may be different, as benthic macroalgae in Plum Island Sound did not show clear isotopic differences either, in contrast to our study of Comau Fjord. This implies that isotopic signatures of terrestrial and marine DIN sources in other estuarine systems may not be as clearly distinguishable as in Comau Fjord.

Our results have implications for the evaluation of $\mathrm{N}$ - and $\mathrm{C}$-cycles in pristine Chilean fjords. We have shown that benthic macrophytes in the intertidal, close to river mouths, have lower $\mathrm{N}$ availability, but use land-derived DIN pools. Land-derived POM, however, plays only a minor role as a food for fixo-sessile suspension feeders. This observation can be explained, on the one hand, by a selective filter or digestion mechanism that prevents uptake of TOM and, on the other hand, by the poor digestibility of TOM, which has to be processed through microbial loops before it can serve as a nutrient source for higher marine organisms. For instance, Mytilus sp. selects particles via the labial palps, and not all particles are digested (Widdows et al. 1979). Terrestrial organic particles are often C-rich and are considered a minor food source for heterotrophic organisms in most coastal zones (Ittekkot \& Laane 1991), which agrees with our isotopic results. Biomarker and isotope studies of a benthic food web in a New Zealand fjord demonstrated that uptake of TOM in an environment similar to Comau Fjord mainly occurs via heterotrophic bacteria that are incorporated by specialised infaunal invertebrates (McLeod \& Wing 2009). These organisms, however, live on benthic softbottom environments, which were not the subject of our investigations.

\section{CONCLUSIONS}

Variable nitrogen sources and availabilities have a great influence on $\delta^{15} \mathrm{~N}$ values and the elemental composition of attached benthic macroalgae in Comau Fjord, but they have less influence on benthic suspen- sion feeders, such as mytilids. $\delta^{15} \mathrm{~N}$ variability of macroalgae occurs along vertical and horizontal salinity gradients in Comau Fjord, presumably due to an admixture of terrestrial DIN sources and marine sources in the low-salinity layer. $\delta^{15} \mathrm{~N}$ values further suggest that, locally, faeces from sea lion and bird colonies provide additional nitrogen sources for benthic macroalgae.

In contrast, attached benthic suspension feeders show little consumption of nitrogen derived from TOM or from macroalgal sources. Instead their $\delta^{15} \mathrm{~N}$ values suggest taxon-specific specialisation on different seston size fractions; a hypothesis that has to be tested by further studies. Among suspension feeders, the few available sponge data show exceptional interspecific variability, which is likely related to their microbial symbionts. In contrast to sponges, vagile predators are in accordance with the commonly used trophic ${ }^{15} \mathrm{~N}$ enrichment models.

The present study shows that organism $\delta^{15} \mathrm{~N}$ values can be a promising tool for food web studies in Patagonian fjords, although isotopically variable nitrogen sources and presumably also endosymbiontic processes are important influences in addition to trophic enrichment. Therefore, such studies require special care regarding site and taxon selection. Undoubtedly, more studies are needed to determine the baseline levels of pristine coastal environments and to decipher the complex N-cycles of the Chilean fjord region. Likewise, further investigations are required to clarify the role of organic matter from terrestrial, but also from macroalgal sources (e.g. Kaehler et al. 2006), in benthic food webs of Patagonian fjords. These datasets may also play an important role in evaluation of the effects of aquaculture and sewage discharge on Patagonian fjord ecosystems.

Acknowledgements. M. Marcotte, J. Biro, T. Roy, K. Talaczek, L. Atwood, D. Thompson, R. Smart, V. Chrapkowski-Llinares and N. Reiff assisted in taking the samples for the present study, and E. Hajdu, with determination of sponges. M. Kühn, M. Oehlerich and N. Torres prepared samples for stable isotope analyses. M. Stoeckl kindly helped with ion chromatography analyses. We thank the persons mentioned and gratefully acknowledge financial support by travel grants from the GeoBio-Center. The comments of 2 anonymous reviewers on an earlier draft of this article were highly appreciated. This is publication Number 46 from Huinay Scientific Field Station.

\section{LITERATURE CITED}

Altabet MA (1988) Variations in nitrogen isotopic composition between sinking and suspended particles: implications for nitrogen cycling and particle transformation in the open ocean. Deep-Sea Res A 35:535-554

Anderson LA, Sarmiento JL (1994) Redfield ratios of remineralization determined by nutrient data-analysis. Global Biogeochem Cycles 8:65-80 
Arntz WE (1999) Magellan-Antarctic: ecosystems that drifted apart. Summary Review. In: Antz WE, Ríos C (eds) Magellan-Antarctic: ecosystems that drifted apart. Institut de Cièncias del Mar, CSIC, Barcelona, p 503-511

Baeta A, Pinto R, Valiela I, Richard P, Niquil N, Marques JC (2009) $\delta^{15} \mathrm{~N}$ and $\delta^{13} \mathrm{C}$ in the Mondego estuary food web: seasonal variation in producers and consumers. Mar Environ Res 67:109-116

Bergmann M, Dannheim J, Bauerfeind E, Klages M (2009) Trophic relationships along a bathymetric gradient at the deep-sea observatory HAUSGARTEN. Deep-Sea Res I 56:408-424

Bode A, Alvarez-Ossorio MT, Varela M (2006) Phytoplankton and macrophyte contributions to littoral food webs in the Galician upwelling estimated from stable isotopes. Mar Ecol Prog Ser 318:89-102

Cifuentes LA, Sharp JH, Fogel M (1988) Stable carbon and nitrogen isotope biogeochemistry in the Delaware estuary. Limnol Oceanogr 33:1102-1115

Cohen RA, Fong P (2005) Experimental evidence supports the use of $\delta^{15} \mathrm{~N}$ content of the opportunistic green macroalgae Enteromorpha intestinalis (Chlorophyta) to determine nitrogen sources to estuaries. J Phycol 41:287-293

Cornelisen CD, Wing SR, Clark KL, Bowman MH (2007) Patterns in the $\delta^{13} \mathrm{C}$ and $\delta^{15} \mathrm{~N}$ signatures of Ulva pertusa: interaction between physical gradients and nutrient source pools. Limnol Oceanogr 52:820-832

Costanzo SD, O'Donohue MJ, Dennison WC, Loneragan NR, Thomas M (2001) A new approach for detecting and mapping sewage impacts. Mar Pollut Bull 42:149-156

> Davy SK, Trautman DA, Borowitzka MA, Hinde R (2002) Ammonium excretion by a symbiotic sponge supplies the nitrogen requirements of its rhodophyte partner. J Exp Biol 205:3505-3511

> Deegan LA, Garritt RH (1997) Evidence for spatial variability in estuarine food webs. Mar Ecol Prog Ser 147:31-47

$>$ DeNiro MJ, Epstein S (1978) Influence of diet on the distribution of carbon isotopes in animals. Geochim Cosmochim Acta 42:495-506

DeNiro MJ, Epstein S (1981) Influence of diet on the distribution of nitrogen isotopes in animals. Geochim Cosmochim Acta 45:341-351

> Dubois S, Jean-Louis B, Bertrand B, Lefebvre S (2007) Isotope trophic-step fractionation of suspension-feeding species: implications for food partitioning in coastal ecosystems. J Exp Mar Biol Ecol 351:121-128

Escribano R, Fernández M, Aranis A (2003) Physicalchemical processes and patterns of diversity of the Chilean eastern boundary pelagic and benthic marine ecosystems: an overview. Gayana Zool 67:190-205

Esteves EL, Lôbo-Hajdu G, Hajdu E (2007) Three new species of Crambe Vosmaer, 1880 (Crambeidae, Poecilosclerida, Demospongiae) from south-east Pacific fjords (Chilean Patagonia), with comments on morphologic characters in the genus. J Mar Biol Assoc UK 87:1367-1378

Evans RD (2001) Physiological mechanisms influencing plant nitrogen isotope composition. Trends Plant Sci 6: 121-126

Fernandez M, Jaramillo E, Marquet PA, Moreno CA and others (2000) Diversity, dynamics and biogeography of Chilean benthic nearshore ecosystems: an overview and guidelines for conservation. Rev Chil Hist Nat 73: 797-830

> Fertig B, Carruthers TJB, Dennison WC, Jones AB, Patus F, Longstaff B (2009) Oyster and macroalgae bioindicators detect elevated $\delta^{15} \mathrm{~N}$ in Maryland's coastal bays. Estuar Coast 32:773-786
Försterra G, Häussermann V (2003) First report on large scleractinian (Cnidaria: Anthozoa) accumulations in coldtemperate shallow water of south Chilean fjords. Zool Verh 345:117-128

Försterra G, Häussermann V (2008) Unusual symbiotic relationships between microendolithic phototrophic organisms and azooxanthellate cold-water corals from Chilean fjords. Mar Ecol Prog Ser 370:121-125

Försterra G, Häussermann V, Lueter C (2008) Mass occurrence of the recent brachiopod Magellania venosa (Terebratellidae) in the fjords Comau and Renihue, northern Patagonia, Chile. PSZN I: Mar Ecol 29:342-347

Fry B, Parker PL (1979) Animal diet in Texas seagrass meadows? $\delta^{13} \mathrm{C}$ evidence for the importance of benthic plants. Estuar Coast Mar Sci 8:499-509

- García-Sanz T, Ruiz-Fernández JM, Ruiz M, García R, González MN, Pérez M (2010) An evaluation of a macroalgal bioassay tool for assessing the spatial extent of nutrient release from offshore fish farms. Mar Environ Res 70: 189-200

Garrison V, Kroeger K, Fenner D, Craig P (2007) Identifying nutrient sources to three lagoons at Ofu and Olosega, American Samoa using $\delta^{15} \mathrm{~N}$ of benthic macroalgae. Mar Pollut Bull 54:1830-1838

> Goering J, Alexander V, Haubenstock N (1990) Seasonal variability of stable carbon and nitrogen isotope ratios of organisms in a North Pacific Bay. Estuar Coast Shelf Sci 30:239-260

Guiry MD, Guiry GM (2009) AlgaeBase. World-wide electronic publication. National University of Ireland, Galway. Available at www.algaebase.org

Häussermann V, Försterra G (2007) Extraordinary abundance of hydrocorals (Cnidaria, Hydrozoa, Stylasteridae) in shallow water of the Patagonian fjord region. Polar Biol 30: $487-492$

Häussermann V, Försterra G (2009) Marine benthic fauna of Chilean Patagonia. Nature in Focus, Puerto Montt

Hayden HS, Blomster J, Maggs CA, Silva PC, Stanhope MJ, Waaland JR (2003) Linnaeus was right all along: Ulva and Enteromorpha are not distinct genera. Eur J Phycol 38:277-294

Heaton THE (1986) Isotopic studies of nitrogen pollution in the hydrosphere and atmosphere: a review. Chem Geol 59:87-102

> Hill JM, McQuaid CD (2008) $\delta^{13} \mathrm{C}$ and $\delta^{15} \mathrm{~N}$ biogeographic trends in rocky intertidal communities along the coast of South Africa: evidence of strong environmental signatures. Estuar Coast Shelf Sci 80:261-268

Hobson KA, Welch HE (1992) Determination of trophic relationships within a high Arctic marine food web using $\delta^{13} \mathrm{C}$ and $\delta^{15} \mathrm{~N}$ analysis. Mar Ecol Prog Ser 84:9-18

Ittekkot V, Laane R (1991) Fate of riverine particulate organic matter. In: Degens E, Kempe S, Richey R (eds) Biogeochemistry of major world rivers. John Wiley \& Sons, New York, NY, p 233-242

Jennings S, Maxwell TAD, Schratzberger M, Milligan SP (2008) Body-size dependent temporal variations in nitrogen stable isotope ratios in food webs. Mar Ecol Prog Ser 370:199-206

Kaehler S, Pakhomov EA, Kalin RM, Davis S (2006) Trophic importance of kelp-derived suspended particulate matter in a through-flow sub-Antarctic system. Mar Ecol Prog Ser 316:17-22

Kamer K, Fong P, Kennison R, Schiff K (2004) Nutrient limitation of the macroalga Enteromorpha intestinalis collected along a resource gradient in a highly eutrophic estuary. Estuaries 27:201-208 
Keeley JE, Sandquist DR (1992) Carbon: freshwater plants. Plant Cell Environ 15:1021-1035

Lapointe BE, Littler MM, Littler DS (1992) Nutrient availability to marine macroalgae in siliciclastic versus carbonaterich coastal waters. Estuaries 15:75-82

Maberly SC, Raven JA, Johnston AM (1992) Discrimination between ${ }^{12} \mathrm{C}$ and ${ }^{13} \mathrm{C}$ by marine plants. Oecologia 91 : 481-492

> Mariotti A, Germon JC, Hubert P, Kaiser P, Letolle R, Tardieux A, Tardieux P (1981) Experimental determination of nitrogen kinetic isotope fractionation: some principles; illustration for the denitrification and nitrification processes. Plant Soil 62:413-430

> McClelland JW, Valiela I, Michener RH (1997) Nitrogenstable isotope signatures in estuarine food webs: a record of increasing urbanization in coastal watersheds. Limnol Oceanogr 42:930-937

McLeod RJ, Wing SR (2009) Strong pathways for incorporation of terrestrially derived organic matter into benthic communities. Estuar Coast Shelf Sci 82:645-653

> Minagawa M, Wada E (1984) Stepwise enrichment of ${ }^{15} \mathrm{~N}$ along food-chains - further evidence and the relation between $\delta^{15} \mathrm{~N}$ and animal age. Geochim Cosmochim Acta 48:1135-1140

Mook WG, Bommerson JC, Staverman WH (1974) Carbon isotope fractionation between dissolved bicarbonate and gaseous carbon dioxide. Earth Planet Sci Lett 22: 169-176

Natelhoffer KJ, Fry B (1988) Controls on natural nitrogen-15 and carbon-13 abundances in forest soil organic matter. Soil Sci Soc Am J 52:1633-1640

> Orejas C, Gili JM, Arntz W (2003) Role of small-plankton communities in the diet of two Antarctic octocorals (Primnoisis antarctica and Primnoella sp.). Mar Ecol Prog Ser 250:105-116

Page HM, Lastra M (2003) Diet of intertidal bivalves in the Ría de Arosa (NW Spain): evidence from stable C and N isotope analysis. Mar Biol 143:519-532

Perakis SS, Hedin LO (2002) Nitrogen loss from unpolluted South American forests mainly via dissolved organic compounds. Nature 415:416-419

Peterson BJ, Fry B (1987) Stable isotopes in ecosystem studies. Annu Rev Ecol Syst 18:293-320

Pickard GL (1971) Some physical oceanographic features of inlets of Chile. J Fish Res Board Can 28:1077-1106

> Post DM (2002) Using stable isotopes to estimate trophic position: models, methods, and assumptions. Ecology 83: 703-718

Ramírez ME, Santelices B (1991) Catálogo de las algas marinas bentónicas de la costa temperada del Pacífico de Sudamérica. Monogr Biol Fac Cienc Bio Pontif Univ Cató Chile 5:1-437

Rau GH, Teyssie JL, Rassoulzadegan F, Fowler SW (1990) ${ }^{13} \mathrm{C} /{ }^{12} \mathrm{C}$ and ${ }^{15} \mathrm{~N} /{ }^{14} \mathrm{~N}$ variations among size-fractionated marine particles: implications for their origin and trophic relationships. Mar Ecol Prog Ser 59:33-38

Redfield AC, Ketchum BH, Richards FA (1963) The influence of organisms on the composition of seawater. In: Hill MN (ed) The composition of seawater. Comparative and descriptive oceanography. The sea: ideas and observations on progress in the study of the seas, Vol 2. Wiley Interscience, London, p 26-77

Riera P, Stal LJ, Nieuwenhuize J, Richard P, Blanchard G, Gentil F (1999) Determination of food sources for benthic invertebrates in a salt marsh (Aiguillon Bay, France) by carbon and nitrogen stable isotopes: importance of locally produced sources. Mar Ecol Prog Ser 187:301-307
Riera P, Stal LJ, Nieuwenhuize J (2000) Heavy $\delta^{15} \mathrm{~N}$ in intertidal benthic algae and invertebrates in the Scheldt estuary (The Netherlands): effect of river nitrogen inputs. Estuar Coast Shelf Sci 51:365-372

Rogers KM (2003) Stable carbon and nitrogen isotope signatures indicate recovery of marine biota from sewage pollution at Moa Point, New Zealand. Mar Pollut Bull 46: 821-827

Santelices B (1989) Algas marinas de Chile. Ediciones Universidad Católica de Chile, Santiago de Chile

Sarmiento JL, Gruber N (2006) Ocean biogeochemical dynamics. Princeton University Press, Princeton, NJ

> Savage C, Elmgren R (2004) Macroalgal (Fucus vesiculosus) $\delta^{15} \mathrm{~N}$ values trace decrease in sewage influence. Ecol Appl 14:517-526

Schoeninger MJ, DeNiro MJ (1984) Nitrogen and carbon isotopic composition of bone-collagen from marine and terrestrial animals. Geochim Cosmochim Acta 48:625-639

Sigman DM, Altabet MA, McCorkle DC, Francois R, Fischer G (1999) The $\delta^{15} \mathrm{~N}$ of nitrate in the Southern Ocean: consumption of nitrate in surface waters. Global Biogeochem Cycles 13:1149-1166

Silva N, Sievers HA, Prado R (1995) Caracteristicas oceanograficas y una proposicion de circulacion, para algunos canales australes de Cile entre $41^{\circ} 20^{\prime} \mathrm{S}$ y $46^{\circ} 40^{\prime} \mathrm{S}$. Rev Biol Mar 30:207-254

Silva N, Calvete C, Sievers H (1998) Masas de agua y circulación para algunos canales australes entre Puerto Montt y Laguna San Rafael, Chile (Crucero CIMAR-Fiordo 1). Cienc Tecnol Mar (Valpso) 21:17-48

Sinniger F, Häussermann V (2009) Zoanthids (Cnidaria: Anthozoa: Zoanthidae) from shallow water of the southern Chilean fjord region with the description of a new genus and two new species. Org Divers Evol 9:23-36

Southwell MW, Popp BN, Martens CS (2008) Nitrification controls on fluxes and isotopic composition of nitrate from Florida Keys sponges. Mar Chem 108:96-108

> Steinarsdóttir MB, Ingolfsson A, Olafsson E (2009) Trophic relationships on a fucoid shore in south-western Iceland as revealed by stable isotope analyses, laboratory experiments, field observations and gut analyses. J Sea Res 61:206-215

Strub PT, Mesías JM, Montecino V, Rutllant J, Salinas S (1998) Coastal ocean circulation off western South America. In: Robinson AR, Brink KH (eds) The sea. John Wiley \& Sons, New York, NY, p 273-313

Struck U, Altenbach AV, Gaulke M, Glaw F (2002) Tracing the diet of the monitor lizard Varanus mabitang by stable isotope analyses $\left(\delta^{15} \mathrm{~N}, \delta^{13} \mathrm{C}\right)$. Naturwissenschaften 89: $470-473$

Thompson SM, Valiela I (1999) Effect of nitrogen loading on enzyme activity of macroalgae in estuaries of Waquoit Bay. Bot Mar 42:519-529

Umezawa Y, Miyajima T, Yamamuro M, Kayanne H, Koike I (2002) Fine-scale mapping of land-derived nitrogen in coral reefs by $\delta^{15} \mathrm{~N}$ in macroalgae. Limnol Oceanogr 47:1405-1416

Vanderklift MA, Ponsard S (2003) Sources of variation in consumer-diet $\delta^{15} \mathrm{~N}$ enrichment: a meta-analysis. Oecologia 136:169-182

van Ofwegen LP, Häussermann V, Försterra G (2006) A new genus of soft coral (Octocorallia: Alcyonacea: Clavulariidae) from Chile. Zootaxa 1219:47-57

- Wada E, Terazaki M, Kabaya Y, Nemoto T (1987) ${ }^{15} \mathrm{~N}$ and ${ }^{13} \mathrm{C}$ abundances in the Antarctic Ocean with emphasis on the biogeochemical structure of the food web. Deep-Sea Res Part A 34:829-841 
Waser NA, Yin $\mathrm{K}, \mathrm{Yu} \mathrm{Z}$, Tada K, Harrison PJ, Turpin DH, Calvert SE (1998) Nitrogen isotope fractionation during nitrate, ammonium and urea uptake by marine diatoms and coccolithophores under various conditions of $\mathrm{N}$ availability. Mar Ecol Prog Ser 169:29-41

Waser NA, Yu Z, Yin K, Nielsen B, Harrison PJ, Turpin DH, Calvert SE (1999) Nitrogen isotopic fractionation during a simulated diatom spring bloom: importance of N-starvation in controlling fractionation. Mar Ecol Prog Ser 179:291-296

Weisz JB, Hentschel U, Lindquist N, Martens CS (2007) Linking abundances and diversity of sponge-associated micro-

Editorial responsibility: Katherine Richardson, Copenhagen, Denmark bial communities to metabolic differences in host sponges. Mar Biol 152:475-483

Widdows J, Fieth P, Worrall CM (1979) Relationships between seston, available food and feeding activity in the common mussel Mytilus edulis. Mar Biol 50:195-207

Wilkinson CR (1978) Microbial associations in sponges. II. Numerical analysis of sponge and water bacterial populations. Mar Biol 49:169-176

Zhu R, Liu Y, Li X, Sun J, Xu H, Sun L (2008) Stable isotope natural abundance of nitrous oxide emitted from Antarctic tundra soils: effects of sea animal excrement depositions. Rapid Commun Mass Spectrom 22:3570-3578

Submitted: December 16, 2009; Accepted: December 27, 2010 Proofs received from author(s): April 3, 2011 